\title{
Social Dominance Orientation: A Personality Variable Predicting Social and Political Attitudes
}

\section{Citation}

Pratto, Felicia, James Sidanius, Lisa M. Stallworth, and Bertram F. Malle. 1994. Social dominance orientation: A personality variable predicting social and political attitudes. Journal of Personality and Social Psychology 67, no. 4: 741-763.

\section{Published Version}

http://dx.doi.org/10.1037/0022-3514.67.4.741

\section{Permanent link}

http://nrs.harvard.edu/urn-3:HUL.InstRepos:3207711

\section{Terms of Use}

This article was downloaded from Harvard University's DASH repository, and is made available under the terms and conditions applicable to Other Posted Material, as set forth at http:// nrs.harvard.edu/urn-3:HUL.InstRepos:dash.current.terms-of-use\#LAA

\section{Share Your Story}

The Harvard community has made this article openly available.

Please share how this access benefits you. Submit a story.

Accessibility 


\title{
Social Dominance Orientation: A Personality Variable Predicting Social and Political Attitudes
}

\author{
Felicia Pratto, Jim Sidanius, Lisa M. Stallworth, and Bertram F. Malle \\ Social dominance orientation (SDO), one's degree of preference for inequality among social groups, \\ is introduced. On the basis of social dominance theory, it is shown that (a) men are more social \\ dominance-oriented than women, (b) high-SDO people seek hierarchy-enhancing professional roles \\ and low-SDO people seek hierarchy-attenuating roles, (c) SDO was related to beliefs in a large num- \\ ber of social and political ideologies that support group-based hierarchy (e.g., meritocracy and rac- \\ ism) and to support for policies that have implications for intergroup relations (e.g., war, civil rights, \\ and social programs), including new policies. SDO was distinguished from interpersonal dominance, \\ conservatism, and authoritarianism. SDO was negatively correlated with empathy, tolerance, com- \\ munality, and altruism. The ramifications of SDO in social context are discussed.
}

Group conflict and group-based inequality are pervasive in human existence. Currently, every continent is enduring some form of ethnic conflict, from the verbal debate over multiculturalism in the United States and Canada to civil war in Liberia and Bosnia. Other conflicts between groups are ancient: the European persecution of Jews, "Holy Wars" waged by Christians and Muslims around the Mediterranean, imperialism in South America, and anti-Black racism in northern Africa and elsewhere. Regardless of the intensity of the conflict, the participants justify their behavior to others by appealing to historical injustices, previous territorial boundaries, religious prohibitions, genetic and cultural theories of in-group superiority, or other such ideologies.

Prompted by the ubiquitous nature of group-based prejudice and oppression, we developed social dominance theory (see Pratto, in press; Sidanius, 1993; Sidanius \& Pratto, 1993a). The theory postulates that societies minimize group conflict by creating consensus on ideologies that promote the superiority of one group over others (see also Sidanius, Pratto, Martin, \& Stallworth, 1991). Ideologies that promote or maintain group inequality are the tools that legitimize discrimination. To work smoothly, these ideologies must be widely accepted within a society, appearing as self-apparent truths; hence we call them $h i$ erarchy-legitimizing myths. ${ }^{1}$ By contributing to consensual or

Felicia Pratto, Lisa M. Stallworth, and Bertram F. Malle, Department of Psychology, Stanford University; Jim Sidanius, Department of Psychology, University of California at Los Angeles.

We are grateful to a number of people for their diligence and creativity in this research: Erron Al-Amin, Jill Andrassy, Sahr Conway-Lanz, Nick Clements, Magda Escobar, Jack Glaser, Louis Ibarra, Kent Harber, John Hetts, Amy Lee, Johanna Jensen, John Moore, Jenn Pearson, Holly Schaefer, Margaret Shih, Stacey Sinclair, Gayatri Taneja, Jack Wang, and Wes Williams. Bob Altemeyer, Monisha Pasupathi, Vernon Schabert, Michael Mitchell, Steve Gangestad, Corinne Kosmitzki, Ted Goertzel, and three anonymous reviewers provided useful comments on a draft of this article.

Correspondence concerning this article should be addressed to Felicia Pratto, Department of Psychology, Jordan Hall, Stanford University, Stanford, California 94305-2130. normalized group-based inequality, legitimizing myths help to stabilize oppression. That is, they minimize conflict among groups by indicating how individuals and social institutions should allocate things of positive or negative social value, such as jobs, gold, blankets, government appointments, prison terms, and disease. For example, the ideology of anti-Black racism has been instantiated in personal acts of discrimination, but also in institutional discrimination against African-Americans by banks, public transit authorities, schools, churches, marriage laws, and the penal system. Social Darwinism and meritocracy are examples of other ideologies that imply that some people are not as "good" as others and therefore should be allocated less positive social value than others.

Thus far, we have given examples of legitimizing myths that enhance or maintain the degree of social inequality. Other ideologies may serve to attenuate the amount of inequality. For example, the "universal rights of man" and the view summarized by "all humans are God's children" are inclusive, egalitarian ideologies that explicitly do not divide persons into categories or groups. To the extent that such ideologies are widely shared, there should be less group inequality. There are, then, two varieties of legitimizing myths: hierarchy-enhancing legitimizing myths, which promote greater degrees of social inequality, and hierarchy-attenuating legitimizing myths, which promote greater social equality.

\section{SOCIAL DOMINANCE ORIENTATION}

Given our theoretical postulate that acceptance of legitimizing myths has significant influence on the degree of inequality in societies, it is quite important to understand the factors that lead to the acceptance or rejection of ideologies that promote or attenuate inequality. Social dominance theory postulates that a

\footnotetext{
${ }^{1}$ The term myth is meant to imply that everyone in the society perceives these ideologies as explanations for how the world is-not that they are false (or true). Social dominance theory is meant only to describe the social and psychological processes that act on these ideologies, not to ascertain whether these ideologies are true, fair, moral, or reasonable.
} 
significant factor is an individual-difference variable called social dominance orientation (SDO), or the extent to which one desires that one's in-group dominate and be superior to outgroups. We consider SDO to be a general attitudinal orientation toward intergroup relations, reflecting whether one generally prefers such relations to be equal, versus hierarchical, that is, ordered along a superior-inferior dimension. The theory postulates that people who are more social-dominance oriented will tend to favor hierarchy-enhancing ideologies and policies, whereas those lower on SDO will tend to favor hierarchy-attenuating ideologies and policies. SDO is thus the central individual-difference variable that predicts a person's acceptance or rejection of numerous ideologies and policies relevant to group relations.

Another way that individuals' levels of SDO may influence their contribution to social equality or inequality is in the kinds of social roles they take on, particularly, roles that either enhance or attenuate inequality. We thus predict that those who are higher on SDO will become members of institutions and choose roles that maintain or increase social inequality, whereas those who are lower on SDO will belong to institutions and choose roles that reduce inequality.

The purpose of the present research was to demonstrate that individual variation in SDO exists and to show that this construct behaves according to the theory outlined above. Specifcally, our goals were (a) to develop a measure of SDO that is internally and temporally reliable, (b) to show that SDO is related to the attitudinal and social role variables specified by social dominance theory (predictive validity), (c) to show that the measure is not redundant with other attitude predictors and standard personality variables (discriminant validity), and (d) to show that SDO serves as an orientation in shaping new attitudes.

\section{HYPOTHESES}

The first set of hypotheses we tested was derived from social dominance theory and concerned those variables to which SDO should strongly relate, termed predictive validity. The second set of hypotheses, termed discriminant validity, states either that SDO should be independent of other variables or that SDO should have predictive value in addition to the effects of these other variables. We also hypothesized that SDO should relate moderately to certain other personality variables, from which SDO is conceptually distinct. The third set of hypotheses we tested concerns SDO's power to predict new social attitudes.

\section{Predictive Validity}

\section{Gender}

The world over, men and women hold different roles with regard to the maintenance of hierarchy. Ubiquitously, men serve as military leaders and hold leadership roles in religious, social, political, and cultural spheres (e.g., Brown, 1991, pp. 110, 137). Moreover, men hold more hierarchy-enhancing attitudes, such as support for ethnic prejudice, racism, capitalism, and rightwing political parties, than do women (e.g., Avery, 1988; Eisler \& Loye, 1983; Ekehammar \& Sidanius, 1982; Shapiro \& Mahajan, 1986; Sidanius \& Ekehammar, 1980; see review by Si- danius, Cling, \& Pratto, 1991). On the basis of these general societal patterns, we have predicted and shown that, on average, men are more social dominance-oriented than women (see Pratto, Sidanius, \& Stallworth, 1993; Sidanius, Pratto, \& Bobo, in press). We tested this hypothesis with the measure of SDO developed in the present research.

\section{Legitimizing Myths}

\section{Ethnic Prejudice}

One of the major kinds of ideology concerning relative group status is ethnic prejudice. In the United States, the most longstanding and widely disseminated version of ethnic prejudice is anti-Black racism. Therefore, we predicted that SDO would be strongly related to anti-Black racism in the present U.S. samples. In the United States, a theoretical and empirical debate about how best to measure anti-Black racism has been conducted for some time (e.g., see Bobo, 1983; McConahay, 1986; Sears, 1988; Sniderman \& Tetlock, 1986a, 1986b). Social dominance theory merely postulates that SDO should predict whatever ideologies are potent within the culture at the time of measurement. From our theoretical viewpoint, it does not matter whether the basis for racism is fairness (e.g., Kluegel \& Smith, 1986), genetic or biblical racial inferiority theories, symbolic racism (e.g., Sears, 1988), or family pathology (e.g., Moynihan, 1965). Any potent ideology that describes groups as unequal and has policy implications is a legitimizing myth and should, therefore, correlate with SDO. During the period the present research was conducted, our subjects' country was engaged in a war against Iraq, so we also measured anti-Arab racism and expected it to correlate with SDO.

\section{Nationalism}

A more general kind of in-group prejudice that can occur in nation-states is nationalism, chauvinism, or patriotism. Kosterman and Feshbach (1989) suggested that procountry feelings (patriotism) can be distinguished from comparative prejudice, that is, that one's country is better than other countries (nationalism), and as such should dominate other countries (chauvinism). Even so, all three reflect attitudinal bias in favor of the national in-group, and thus we postulated that patriotism, nationalism, and chauvinism would all be significantly related to SDO.

\section{Cultural Elitism}

All societies share the idea that one of the defining features of those who belong to their society (are part of the in-group, or are considered by them to be human) is that they are "cultured." In some societies, including English and American society, an elitist ideology built on the cultured-not cultured distinction postulates that the elite class has "culture" not shared by middle- and working-class people and is therefore more deserving of the "finer things in life." We term this legitimizing myth $\mathrm{cul}$ tural elitism, and we expected it to correlate with SDO as well.

\section{Sexism}

We believe that antifemale sexism is a ubiquitous legitimizing myth, although, as with ethnic prejudice, the content basis of 
sexist ideology varies widely with religion, cultural history, and technology. In the present U.S. samples, we used scales that assess sexism as the extent to which people believe men and women are "naturally" different and should have different work roles outside and inside the home (Benson \& Vincent, 1980; Rombough \& Ventimiglia, 1981) and the extent to which people believe that women rather than men can be blamed for unwanted sexual advances such as rape and sexual harassment (Burt, 1980). We predicted that all of these would be positively correlated with SDO, even controlling for subject sex.

\section{Political-Economic Conservatism}

Political-economic conservatism is associated with support for capitalism versus socialism (e.g., Eysenck, 1971). Given that capitalism implies that some people and businesses should thrive, while those who are less "competitive" should not, we consider political-economic conservatism to be a hierarchy-enhancing legitimizing myth that should positively correlate with SDO (see also Sidanius \& Pratto, 1993b). Other policies supported by conservatives, such as that women should stay home with children and that the USSR must be kept in its place, divide people into groups "deserving" different treatment, so we feel conservatism generally can be viewed as a legitimizing myth. In fact, Wilson's extensive work on the body of attitudes that make up conservatism shows that a preference for hierarchical social relationships is one of conservatism's many dimensions (Wilson, 1973, p. 22).

\section{Noblesse Oblige}

A hierarchy-attenuating ideology that exists in many cultures is that those with more resources should share them with those who have fewer resources (e.g., the Marxist maxim, "From each according to his [sic] ability, to each according to his need," and the potlatch custom of the Kwakiutl). The English-American version is called noblesse oblige, which we expected to be negatively correlated with SDO.

\section{Meritocracy}

Another hierarchy-enhancing ideology is that wealth and other social values are already distributed appropriately, based on the deservingness of the recipients. The Protestant work ethic and just world theory are examples of meritocratic ideologies, so we administered standard measures of belief in the Protestant work ethic and belief in a just world and predicted that they would be positively correlated with SDO. In the United States, attributions for poverty due to laziness or to some other inherent fault in the poor are predicated on the idea that equal opportunity is available to all (Kluegel \& Smith, 1986), so we wrote an equal opportunity scale and predicted that it would correlate positively with SDO.

\section{Social Policy Attitudes}

According to social dominance theory, individuals who are social dominance oriented will favor social practices that maintain or exacerbate inequality among groups and will oppose social practices that reduce group inequality. The particular social policies that correlate with SDO may vary from society to soci- ety, but we predicted that SDO would relate to support for, or opposition to, the following policies in U.S. samples.

\section{Social Welfare, Civil Rights, and Environmental Policies}

We expected SDO to correlate with opposition to social policies that would reduce inequality between U.S. nationals and foreigners or immigrants, rich and middle class or poor, men and women, ethnic groups, heterosexuals and homosexuals, and humans versus other species. As such, we measured our subjects' attitudes toward a variety of government social programs, racial and sexual discrimination laws, gay and lesbian rights, domination of foreigners, and environmental policies. In several samples we also assessed attitudes toward "interracial dating" and "interracial marriage," because miscegenation has been central to the U.S. racial policy debate.

\section{Military Policy}

Because the military is a symbol of nationalism and can be one of the chief means of domination of one nation over others, we expected SDO to correlate positively with expressed support for military programs and actions.

\section{Punitive Policies}

Despite its stated creed to enact equality before the law, the U.S. criminal justice system shows class and ethnic bias at all levels from arrest to plea bargaining to sentencing (e.g., Bienen, Alan, Denno, Allison, \& Mills, 1988; General Accounting Office, 1990; Kleck, 1981; Nickerson, Mayo, \& Smith, 1986; Paternoster, 1983; Radelet \& Pierce, 1985; Reiman, 1990; Sidanius, 1988). As one example, in a review of 1,804 homicide cases in South Carolina, Paternoster (1983) found that in cases where Blacks killed Whites, rather than other Blacks, prosecutors were 40 times more likely to request the death penalty. For this reason, we expected support for "law and order" or punitive policies, particularly the death penalty, to be positively related to SDO (see also Mitchell, 1993; Sidanius, Liu, Pratto, \& Shaw, 1994).

\section{Discriminant Validity \\ Interpersonal Dominance}

SDO, or preference for unequal relationships among categories of people, is conceptually distinguishable from the common personality conception of interpersonal dominance, which concerns the extent to which individuals like to be in charge and are efficacious. For example, people who score high on the California Personality Inventory (CPI) Dominance scale are confident, assertive, dominant, and task oriented, whereas people who score low are unassuming and nonforceful (Gough, 1987, p. 6). People who score high on the Jackson Personality Research Form (JPRF) Dominance scale attempt to control their environments and influence or direct other people; they are forceful, decisive, authoritative, and domineering (Jackson, 1965). We tested this theoretical distinction between social and task or interpersonal dominance by using the CPI and JPRF Dominance subscales in several samples reported here. We predicted that SDO would not correlate with these two measures. 


\section{Authoritarianism}

There is clearly some theoretical similarity in the effects of social dominance theory's SDO construct and authoritarian personality theory's authoritarian construct (see Adorno, Frenkel-Brunswik, Levinson, \& Sanford, 1950). High-SDO people and authoritarian personalities are theorized to be relatively conservative, racist, ethnocentric, and prejudiced, and they should show little empathy for lower status others. Our conception of SDO, however, differs from classical authoritarianism in several respects. First, classical authoritarian theorists viewed authoritarianism as an aberrant and pathological condition and as a form of ego-defense against feelings of inadequacy and vulnerability (see also Frenkel-Brunswik, 1948, 1949). SDO, however, is not conceived of in clinical terms, as an aberrant personality type, or as a form of ego-defense. Rather, SDO is conceived of as a "normal" human propensity on which people vary. Second, authoritarian personality theory emphasized the sources of authoritarianism as springing from psychodynamic processes. Specifically, Adorno et al. (1950) postulated that strict and harsh parental styles would provoke conflicts between the child and parents that would be "unresolved." As a way of resolving these, the child as an adult would submit to authorities and be intolerant of those who would not. In contrast, we theorize that such a personal history is unnecessary to developing a relatively high SDO tendency. Rather, both temperament and socialization probably influence one's level of SDO. Third and most important, whereas authoritarianism is primarily conceived as a desire for individual dominance resulting from experiences with authority figures, SDO is regarded as the desire that some categories of people dominate others. Because the two constructs are defined differently, measurements of each should not be highly correlated.

Given that authoritarianism should predict many of the same variables we postulate SDO should predict, it is important for us to show that SDO has explanatory value in addition to authoritarianism. We tested the "marginal utility" of the SDO construct by testing whether correlations between SDO and support for legitimizing myths and policies are significant after partialing out authoritarianism.

\section{Conservatism}

Political-economic conservatism serves as a legitimizing myth in our theory, and thus we expect it to correlate positively with SDO. Conservatism is also a well-known robust predictor of social and political attitudes (e.g., Eysenck \& Wilson, 1978; Wilson, 1973). To show that SDO has utility in addition to political-economic conservatism, we tested whether SDO substantially correlated with social attitudes after partialing out conservatism.

\section{Standard Personality Variables}

Because we think our concept of SDO is a yet unstudied personality dimension, we expected it to be independent of other standard personality variables such as self-esteem and the BigFive personality dimensions: Extraversion, Agreeableness, Openness, Neuroticism, and Conscientiousness (see Costa \& MacRae, 1985; John, 1990, for reviews).

\section{Empathy, Altruism, Communality, and Tolerance}

People who are highly empathic with others would seem to be less prejudiced and discriminatory against out-groups. Thus, it is reasonable to expect a general concern for other people to be negatively correlated with SDO. Similarly, any general prosocial orientation might mitigate prejudiced feelings and behaviors toward out-group members, so altruism should be negatively correlated with SDO. Furthermore, people who are quite inclusive in their definitions of what constitutes an in-group should be less able to discriminate against out-groups, so we expected communality to be negatively correlated with SDO. And finally, because tolerance is the antithesis of prejudice, we might expect that a general measure of tolerance would be negatively correlated with a general desire for in-group superiority. We used Davis' (1983) multidimensional empathy scale, Super and Nevill's (1985) altruism subscale, the Personal Attribute Questionnaire (PAQ) Communality scale (Spence, Helmreich, \& Stapp, 1974), and the Jackson Personality Inventory (JPI) Tolerance scale (Jackson, 1976) to test these hypotheses. If SDO has merit as a new personality variable, none of these correlations should be very high.

\section{PRESENT RESEARCH}

\section{Overview}

We examined data from 13 samples to test the predictive and discriminant validity and reliability of our measure of SDO. Our logic in using this large number of samples is to examine statistically significant results that are reliable across samples. We organized the results by topic, but we report the results in each sample so that the reader can see the magnitude of effects in each sample and the stability of the results across samples. At the end of the Results section, we provide a summary of the results in the form of meta-analyses.

\section{Data Collection}

Generally, subjects were college students who participated in a study called "Social Attitudes" for partial course credit. All of their responses were anonymous and confidential, and they completed batteries of self-administered questionnaires. Subjects in Samples 2, 3b, 5, 6, 8, 9, and 13 spent about $1 \mathrm{hr}$ in our laboratory completing the questionnaires. The experimenter described the study as designed to measure students' social attitudes and personal preferences. Subjects in Samples 1 and 13 completed the SDO scale after participating in unrelated experiments, and subjects in the remaining samples completed the SDO scale and follow-up scales in two consecutive mass-testing sessions normally conducted on subject pool participants. All subjects completed a demographic background sheet and our 14-item SDO scale intermixed with related items, a Nationalism scale based on Kosterman and Feshbach's (1989) measure, along with other attitude or experience measures, each having their own instructions and response scales. We also administered some standard personality or attitude scales according to the instructions of their authors. In several samples we also administered ideological (legitimizing myths) or policy attitude items on a questionnaire entitled "Policy Issues Questionnaire." 


\section{Measures}

\section{$S D O$}

In previous archival studies, we measured proxies for SDO using items dealing with equality from the National Election Study or the S6 Conservatism scale (see Sidanius, 1976). In developing the present measure of SDO, we tested over 70 items whose content we felt related to SDO or to constructs one can define as separate but that might be considered adjacent to SDO (e.g., nationalism and prestige-striving), following Loevinger's (1957) suggestion about scale construction. However, on the basis of our desire to develop a simple, unidimensional scale that is balanced, we selected 14 items from this extensive questionnaire as the SDO scale. The selected items concerned the belief that some people are inherently superior or inferior to others and approval of unequal group relationships (see items in Appendix A). The 14-item SDO scale was balanced in that half the items indicated approval of inequality and half indicated approval of equality (see items in Appendix A). We assume that these items tap a latent construct and so we are interested in the relationships between the scale mean and other measures rather than relationships between individual SDO items and other measures.

SDO is an attitudinal orientation, so instructions read, "Which of the following objects or statements do you have a positive or negative feeling towards? Beside each object or statement, place a number from ' 1 ' to ' 7 ' which represents the degree of your positive or negative feeling." The scale was labeled very positive (7), positive (6), slightly positive (5), neither positive nor negative (4), slightly negative (3), negative (2), and very negative (1).

The order of the SDO items and the filler items differed among Form A, completed by Samples 1, 2, 3, and 4; Form B, completed by Samples 5, 6, 7, 8, and 12; and Form C, completed by Samples 9,10 , and 11. The format and instructions for the three forms were identical, and we saw no evidence that results pertinent to reliability or validity issues differed across the questionnaire form. Subsequent to the present research, we have used just the 14 items on a questionnaire and found reliability coefficients of .90 and predictive validity results similar to those reported below.

\section{Political-Economic Conservatism}

Some of the standard scales assessing political-economic conservatism actually measure individuals' support for particular social policies (e.g., the C-scale, Wilson \& Patterson, 1968). Because we wished to measure political-economic conservatism separately from policy attitudes, and because we wanted to use a measure that should not vary with time and place, we used a self-identified liberal-conservative measure in all samples. On the demographic background sheet, the political-economic conservatism question read, "Use one of the following numbers to indicate your political views in the accompanying categories." Below these instructions was a scale labeled very liberal (1), liberal (2), slightly liberal (3), middle of the road (4), slightly conservative (5), conservative (6), and very conservative (7) and a blank next to each type of issue: "foreign policy issues," "economic issues," and "social issues." Political-economic conservatism was the mean of self-ratings on these three items.

\section{Authoritarianism}

Authoritarianism research has been fraught with measurement difficulties. After surveying the authoritarianism measurement literature, we decided to administer two rather different measures of authoritarianism, both of which are balanced: the Right Wing Authoritarian (RWA) scale by Altemeyer (1981) and Goertzel's (1987) bipolar personality measure. Goertzel (1987) intended his adjective checklist to measure the personality rather than the ideological aspect of authoritarianism, but did show that it correlates with attitudes toward policies falling along toughness and consistency dimensions. Altemeyer's (1981) scale is the only other internally reliable measure of authoritarianism that is close to the original conception of authoritarianism, including conventionalism, authoritarian submission, and authoritarian aggression (see Duckitt, 1989, for a review).

\section{Original Legitimizing Myths and Policy Attitudes}

The consent form and instructions informed subjects that their opinions and preferences toward a variety of ideas, kinds of people, events, and so forth would be measured. On our "Policy Issues Questionnaire" we included items from various legitimizing myth or policy attitude scales. Items from each scale were interspersed throughout the questionnaire. Next to each item was a 1-7 scale, and the instructions read, "Which of the following objects, events, or statements do you have a positive or negative feeling towards? Please indicate your feelings by circling the appropriate number alongside each item. Use one of the following responses. Remember, your first reaction is best. Work as quickly as you can." The scale points were labeled very negative (1), negative (2), slightly negative (3), uncertain or neutral (4), slightly positive (5), positive (6), and very positive (7).

Items from the original legitimizing myths and policy attitude scales were selected for their content and for their internal reliability across samples. These scales are shown in Appendix B. Several personality measures were used as well; these are described in the Method section.

\section{Method}

\section{Subjects}

Although our 1,952 subjects were college students, they represent some diversity in terms of sex, ethnicity, and income groups, coming from public and private universities in California. Demographic information about the samples is shown in Table 1.

\section{Samples and Procedures}

Sample 1 (spring 1990) consisted of 98 University of California at Berkeley undergraduates who completed the CPI Dominance, Flexibility, and Capacity for Status subscales (Gough, 1987), the JPRF Dominance subscale (Jackson, 1965), the JPI Tolerance subscale (Jackson, 1976), and the Rosenberg (1965) Self-Esteem Scale (RSE).

Sample 2 (fall and winter 1990-1991) consisted of 463 San Jose State University (SJSU) undergraduates who completed the CPI and JPRF Dominance subscales; Mirels and Garrett's (1971) Protestant Work Ethic Scale; the Just World Scale (Rubin \& Peplau, 1975); the fourfactor Interpersonal Reactivity Index (IRI), which measures empathy (Davis, 1983); a number of policy attitude measures; and some demographic descriptors. 
Table 1

Description of Samples

\begin{tabular}{|c|c|c|c|c|c|c|c|c|c|c|c|c|c|c|}
\hline \multirow[b]{2}{*}{ Measure } & \multicolumn{14}{|c|}{ Sample } \\
\hline & 1 & 2 & $3 a$ & $3 b$ & 4 & 5 & 6 & 7 & 8 & 9 & 10 & 11 & 12 & 13 \\
\hline \multicolumn{15}{|c|}{ Age and gender breakdown } \\
\hline $\begin{array}{l}n \\
\text { Age range }\end{array}$ & $\begin{array}{c}98 \\
17-34\end{array}$ & $\begin{array}{c}463 \\
15-56\end{array}$ & $\begin{array}{c}81 \\
17-21\end{array}$ & $\begin{array}{c}57 \\
17-21\end{array}$ & 190 & $\begin{array}{c}144 \\
17-35\end{array}$ & $\begin{array}{c}49 \\
17-23\end{array}$ & 224 & $\begin{array}{c}115 \\
17-59\end{array}$ & $\begin{array}{c}97 \\
17-36\end{array}$ & 231 & 100 & 135 & 46 \\
\hline$\%$ men & 50 & 47 & & 51 & 47 & 49 & 69 & 50 & 40 & 33 & 54 & & 59 & 100 \\
\hline$\%$ women & 50 & 53 & & 49 & 53 & 51 & 31 & 50 & 60 & 67 & 46 & & 41 & 0 \\
\hline
\end{tabular}

Ethnic breakdown

\begin{tabular}{|c|c|c|c|c|c|c|c|c|c|c|c|c|}
\hline$\%$ Euro-American & 48 & 38 & 58 & 38 & 53 & 59 & 49 & 29 & 19 & 67 & 50 & 52 \\
\hline$\%$ Asian-American & 23 & 40 & 16 & 40 & 24 & 24 & 25 & 51 & 45 & 22 & 33 & 33 \\
\hline$\%$ Hispanic & 13 & 8 & 4 & 8 & 10 & 15 & 10 & 14 & 17 & 4 & 10 & 11 \\
\hline$\%$ Black & 15 & 5 & 14 & 5 & 8 & 2 & 6 & 2 & 10 & 4 & 4 & 0 \\
\hline \% Arab-American & 1 & 2 & 6 & 2 & 0 & 0 & 1 & 3 & 8 & 1 & 1 & 4 \\
\hline
\end{tabular}

\begin{tabular}{lrrrrr} 
Under 20K & 12 & 10 & 21 & 6 & 17 \\
$20-30 \mathrm{~K}$ & 9 & 8 & 16 & 6 & 19 \\
$30-40 \mathrm{~K}$ & 11 & 5 & 12 & 8 & 13 \\
$40-55 \mathrm{~K}$ & 17 & 10 & 8 & 10 & 13 \\
$55-70 \mathrm{~K}$ & 20 & 10 & 19 & 10 & 17 \\
$70-100 \mathrm{~K}$ & 14 & 21 & 14 & 19 & 12 \\
$100-150 \mathrm{~K}$ & 8 & 15 & 6 & 19 & 17 \\
$150-200 \mathrm{~K}$ & 5 & 13 & 3 & 11 & 15 \\
$200 \mathrm{~K}+$ & 5 & 8 & 1 & 11 & 5 \\
\hline
\end{tabular}

Note. Missing numbers indicate that information was not available. Samples 4, 7, 10-13 are probably similar in age distribution and range to Sample 3. Income was self-reported annual family income in thousands of dollars.

Sample 3a (September, 1990) consisted of 81 Stanford University undergraduates who completed the SDO scale as part of a mass-testing session. Sample 3b included 57 subjects from the same population who participated in a study in our lab in December, 1990, during which they completed the SDO scale again and a number of attitude and personality measures. The overlap of these two samples $(N=25$ with complete data) was used to assess the cross-time reliability of SDO.

Sample 4 (January, 1991) consisted of 190 Stanford University undergraduates who completed the SDO scale and an attitude scale about the Iraq war assessing environmental concerns in the war, anti-Arab racism, willingness to sacrifice for the war, willingness to restrict civil liberties for the war effort, and support for the use of military force by the United States against Iraq.

Sample 5 (fall 1991) consisted of 144 SJSU undergraduates who completed the RSE (Rosenberg, 1965), the Rombough and Ventimiglia (1981) Tri-Dimensional Sexism Scale, the Sexist Attitudes Toward Women Scale (Benson \& Vincent, 1980), the Rape Myths Scale (Burt, 1980 ), the Altruism subscale from the Values Scale (Super \& Nevill, 1985 ), and the IRI (Davis, 1983). We also measured policy attitudes toward gay rights, women's equality policies, militarism, punitiveness, racial policies, and environmental policies. In addition, we measured ideologies such as anti-Black racism, elitism, patriotism, belief in equal opportunity, and opposition to miscegenation.

Sample 6 (September, 1991) consisted of 49 Stanford undergraduates who completed the same measures as subjects in Sample 5 .

Sample 7 (September, 1991) consisted of 224 Stanford undergraduates who completed a battery of personality questions, including Malle and Horowitz's (1994) bipolar descriptions of Factors I (Extraversion), II (Agreeableness), IV (Neuroticism), and V (Conscientiousness) of the Big-Five personality dimensions (see John, 1990, for a review). A few weeks later, in the 3 days including and following the day Clarence Thomas was confirmed to the Supreme Court, those subjects who had given their prior permission were telephoned and asked four questions about their opinions regarding this Supreme Court nomination. In all, 149 subjects were reached by telephone, and the response rate was $100 \%$.

Sample 8 (February, 1992) consisted of 115 Stanford undergraduates who completed the PAQ (Spence et al., 1974), CPI Dominance scale (Gough, 1987), JPRF Dominance scale (Jackson, 1965), JPI Tolerance scale (Jackson, 1976), IRI (Davis, 1983), RSE (Rosenberg, 1965), a post-Iraq war attitude survey, a general war attitude survey, and a number of other policy attitude measures similar to those in Sample 5.

Sample 9 (April, 1992) consisted of 97 SJSU undergraduates. They completed the CPI and JPRF Dominance subscales; the JPI Tolerance subscale; the IRI; the Protestant Work Ethic Scale; all 19 of the authoritarian bipolar adjective choices (Goertzel, 1987); Altemeyer's (1981) 30-item RWA Scale; John, Donahue, and Kentle's (1992) Big-Five Personality Inventory; the PAQ; McConahay's (1986) Modern Racism Scale; and Katz and Hass' (1988) Pro-Black, Anti-Black, and Humanitarian-Egalitarian Scales. They also completed a number of policy attitude items similar to those for Sample 5.

Sample 10 (March, 1992) consisted of 231 Stanford undergraduates who completed the SDO scale. Two weeks later, 176 of these subjects completed a comprehensive survey about their ideologies and general attitudes about the death penalty and their attitude about the execution of Robert Alton Harris, who was executed by the state of California the day before the survey was administered.

Sample 11 (March, 1991) consisted of 100 Stanford University undergraduates who completed the SDO scale and a battery of other questionnaires including Snyder's (1974) self-monitoring scales; Fenigstein, Scheier, and Buss' (1975) Self-Consciousness scales; and Malle and Horowitz' (1994) bipolar adjective versions of Factors I and IV of the BigFive personality dimensions.

Sample 12 (January, 1992) included 139 Stanford undergraduates 
who completed the SDO scale in a mass-testing session. Of these, 70 also completed Malle and Horowitz' (1994) measures of Factors I and IV.

Sample 13 included 46 undergraduate men at Stanford during 19901991 who were selected to be in an experiment on the basis of having either extremely high or low SDO scores in Samples 3, 4, and 11 . They participated in the experiment between 6 weeks and 8 months after their first testing and completed the SDO scale again.

\section{Results}

We first present the internal and temporal reliability of our SDO scale. We then examine whether this measure related to the ideological, policy attitude, and hierarchy role variables predicted by social dominance theory. We show that SDO was either independent of other personality variables with which it might be confused or that it predicted the attitudinal outcomes over and above the effects of these other variables. We also show that it was not redundant with other personality measures. Finally, we show that SDO predicted new social and political attitudes. To summarize the results across samples, we report simple averages of the internal reliability coefficients across samples and averaged correlations across samples using Fisher's $z$-to-r transformation.

\section{Reliability of the SDO Measure}

\section{Unidimensionality}

We conducted two kinds of analyses to confirm that the 14 SDO items assessed a single construct. First, within each sample, principal-components analyses of the 14 SDO items showed that a single dimension captured the bulk of the variance in these items. That is, there was a precipitous drop between the values of the first and second eigenvalues in every sample. Second, we subjected our largest sample, Sample $2(N$ $=446$ with complete data on all SDO items) to confirmatory factor analysis. Using maximum-likelihood estimation, we tested a model in which all 14 items were driven by a single latent construct. Each item had a statistically significant relationship to the latent factor ( $p s<.0001$ ). By freeing only 3 of 91 possible off-diagonal elements of the $\theta_{\delta}$ matrix, ${ }^{2}$ we obtained a satisfactory $\chi^{2} / d f$ ratio of 2.89 (e.g., Carmines \& McIver, 1981), suggesting that our data are consistent with a model in which a single dimension underlies responses to all the items. Thus, the 14 items appear to measure a unitary construct.

\section{Internal Reliability}

Item statistics showed that the 14-item SDO scale showed good internal reliability across all samples, averaging $\alpha=.83$ (see internal reliability coefficients and item statistics by sample in Table 2). Item analyses also showed that all items were highly correlated with the remainder of the scale in every sample. The average lowest item-total correlation across samples was .31 and the average highest item-total correlation across samples was .63. Item 7 had the lowest item-total correlation in 4 of 12 independent samples $(Z=3.52, p<.001)$. Item 9 had the highest item-total correlation in 3 samples $(Z=2.40, p<.01)$. No other items were either the most or least correlated across samples in numbers that differed from chance using a binomial test.

\section{Stability of SDO Measure Over Time}

We measured the stability of scores on our scale over time in two samples. Twenty-five of the subjects in Sample 3 were tested on SDO twice at a 3-month interval. Their SDO scores substantially correlated from Time 1 to Time $2(r=.81, p<.01)$. The mean difference from Time 1 to Time 2 was 0.09 on a 7 -point scale, which did not differ reliably from zero $(t<1)$. In contrast, the Time 1-Time 2 correlation for the 10-item RSE was .50.

Sample 13 consisted of 46 of the highest and lowest scoring men on the SDO scale from Samples 3, 4, and 11, who completed that scale again some months later. The correlation in this sample from Time 1 to Time 2 was $.84(p<.001)$, and the mean difference in scores from Time 1 to Time 2 was essentially zero $(M=0.03, t<1$; for the high group, $M=-0.03$ and for the low group, $M=0.09$ ). All of the subjects first classified as "high" or "low" on SDO met this criterion again in the second testing. The near-zero mean changes within both groups are particularly telling because one could have expected at least some regression toward the mean. Thus, even in different testing contexts, our SDO measure appears highly stable in the short term.

\section{Predictive Measures}

\section{Gender Differences}

The gender difference we expected showed in all but two samples; men were higher on SDO than women (see point-biserial correlations in Table 2).

\section{SDO and Hierarchy Role}

A question on the demographic background questionnaire asked subjects in what sector of the economy they intended to work after graduation. There were 20 career choices provided. Theoretically, we define those whose work is primarily aimed at protecting, serving, or benefiting elite members of society more than oppressed members of society "hierarchy-enhancing." Those whose work benefits the oppressed more than elites we define as "hierarchy-attenuating." As such, we classified subjects as (a) hierarchy enhancers (those intending careers in law, law enforcement, politics, and business); (b) "middlers" who would not obviously attenuate or enhance inequality through their professional work, such as science and sales; or (c) hierarchy attenuators (those intending to be in such professions as social work or counseling; see also Sidanius, Pratto, Martin, \& Stallworth, 1991). We predicted that hierarchy enhancers would have higher SDO levels than hierarchy attenuators, and that middlers' SDO levels would fall somewhere between the other two. Sample 2 was large enough to test this hypothesis; we also combined Samples 5, 6, 8, and 9 to replicate the test. Because more women tend to go into hierarchy-attenuating careers, and because we know that SDO exhibits a gender difference, we also included subject sex as an independent variable along with hierarchy role. SDO was the outcome variable in simultaneous regression-style analyses of variance (ANOVAs)

\footnotetext{
2 The freed elements of the matrix corresponded to Items 8 and 9 , Items 2 and 4, and Items 10 and 11 in Apendix A.
} 
Table 2

Coefficient Alphas, Correlation With Subject Gender, and Average Item Means and Variances by Sample for 14-Item Social Dominance Orientation Scale

\begin{tabular}{|c|c|c|c|c|c|c|c|c|c|c|c|c|c|}
\hline \multirow[b]{2}{*}{ Measure } & \multicolumn{13}{|c|}{ Sample } \\
\hline & 1 & 2 & $3 a$ & $3 b$ & 4 & 5 & 6 & 7 & 8 & 9 & 10 & 11 & 12 \\
\hline$\alpha$ & .85 & .83 & .84 & .85 & .84 & .81 & .84 & .89 & .82 & .80 & .83 & .81 & .83 \\
\hline$r_{\mathrm{pbi}}$ & $.29^{* *}$ & $.27^{* *}$ & $.32^{* *}$ & $.31^{*}$ & $.32^{* *}$ & .11 & $.36^{*}$ & $.28^{*}$ & $.27^{* *}$ & .03 & $.30^{* *}$ & - & $.26^{* *}$ \\
\hline$M$ & 2.44 & 2.74 & 2.55 & 2.31 & 2.59 & 2.97 & 2.50 & 2.59 & 3.02 & 3.12 & 3.13 & 2.91 & 2.60 \\
\hline Variance & 0.14 & 0.22 & 0.18 & 0.17 & 0.21 & 0.40 & 0.24 & 0.23 & 0.18 & 0.36 & 0.66 & 0.27 & 0.23 \\
\hline
\end{tabular}

Note. Positive correlations with gender indicate that men were higher than women.

$* p<.05 . \quad * * p<.01$.

with planned contrasts. In Sample 2, the results were as expected: Those who intended to work in hierarchy-attenuating professions had lower SDO levels $(M=2.28)$ than did middlers $(M=2.72), F(1,432)=5.49, p<.05$, and also lower levels than those intending to work in hierarchy-enhancing professions $(M$ $=2.88), F(1,432)=10.21, p<.01$. Men also had higher SDO levels $(M=3.03)$ than women $(M=2.51), F(1,432)=36.86, p$ $<.001$. In the merged sample, hierarchy attenuators again had lower SDO levels $(M=2.64)$ than hierarchy enhancers $(M=$ 3.09), $F(1,378)=5.01, p<.05$. Middlers' SDO levels were in the middle $(M=2.94)$ and were not distinguishable from those of either enhancers or attenuators. Again, men $(M=3.07)$ had higher SDO levels than women $(M=2.90), F(1,378)=3.72, p$ $=.05$. Results from both these large samples indicate that intended hierarchy attenuators did indeed have lower SDO levels than intended hierarchy enhancers, even after controlling for subjects' sex.

\section{SDO and Hierarchy-Legitimizing Myths}

We hypothesized that SDO should be related to any social or political ideology that helps legitimize group-based inequality.

Ideologies. The three-item index of self-described political ideology had good internal reliability, averaging $\alpha=.78$ across samples (see Table 3 ). SDO correlated positively and significantly with political-economic conservatism in 7 of 8 samples, averaging $r=.38$; conservatives were higher on SDO than liberals (see Table 3). The scales measuring meritocratic ideologies, the Protestant Work Ethic and Just World Scales, had fairly low internal reliabilities in all samples, considering that they are 19and 20 -item scales, respectively (see Table 3 ). In a Stanford sample (Sample 3b), but not in two samples from SJSU (Samples 2 and 9), the Protestant Work Ethic Scale and Just World Scale had significant positive correlations with SDO (see Table 3). This suggested to us that variations in the cultural background of these samples may affect the ideologies known to and accepted by them. Results from our demographic questionnaire showed that compared with Stanford, SJSU tends to have more first-generation American, more Catholic, and fewer EuroAmerican students.

The other legitimizing myth scales that we constructed fared better (see items for all other scales Appendix B). The nationalism, patriotism, cultural elitism, and equal opportunity measures all had good internal reliability and were positively correlated with SDO ( $r$ s ranged from .22 to .67 ), with only one ex- ception (see Table 3). These correlations showed that the more subjects tended to prefer group dominance in general, the more nationalistic and patriotic they were (average $r s=.51$ and .45 , respectively) and the more they subscribed to cultural elitism (average $r=.40$ ) and equal opportunity ideologies (average $r=$ 46). As predicted, the noblesse oblige scale was strongly negatively correlated with SDO in every sample, ranging from -.39 to -.69 (see Table 3). In Samples 1, 3a, and 7 (not shown in Table 3), SDO correlated $-.47,-.56$, and -.67 with noblesse oblige $(p s<.01)$, for an overall average correlation of -.54 .

Ethnic prejudice. SDO was strongly correlated with our anti-Black racism measure in every sample, ranging from .42 to .65 and averaging .55 (see Table 3). In Sample 4, we also measured anti-Arab racism $(\alpha=.73)$, which correlated with SDO $(r=.22, p<.05)$. In Sample 9, we administered McConahay's (1986) seven-item Modern Racism Scale $(\alpha=.79)$, which correlated .53 with SDO. Katz and Hass' (1988) 10-item Pro-Black Scale $(\alpha=.68)$ was negatively correlated with $\operatorname{SDO}(r=-.38, p$ $<.01$ ), and their 10-item Anti-Black Scale $(\alpha=.62)$ was positively correlated with SDO $(r=.30, p<.01)$. These results, using rather different racism measures, are consistent with the idea that generalized preference for group dominance drives belief in culturally specific forms of ethnic prejudice.

Sexism. We assessed antifemale sexism in Samples 5 and 6 with several measures, all of which proved to be internally reliable. These measures were highly correlated with SDO ( $r$ ranging from .34 to .63 ; see Table 4). Across both samples and all sexism measures, the average correlation was .47. Partial correlations controlling for gender with SDO were also reliable and of about the same magnitude. For this reason, the large correlations between SDO and sexism cannot be attributed to gender differences on SDO or sexism measures.

In summary, all of the measured ideologies (hierarchy-legitimizing myths) except the Protestant Work Ethic Scale and Belief in a Just World Scale were reliably correlated with SDO in the expected directions across virtually all samples. SDO was most strongly related with ideologies concerning group prejudice against other nations, ethnic groups, and women.

\section{SDO and Policy Attitudes}

We hypothesized that SDO would predict support for social policies with implications for the distribution of social value among groups. We assessed attitudes toward chauvinist policies (United States dominating other national groups), law and or- 
Table 3

Coefficient Alphas of Legitimizing Myth Scales and Correlations With Social Dominance Orientation Sample

\begin{tabular}{|c|c|c|c|c|c|c|c|c|c|}
\hline Measure & $\begin{array}{l}\text { No. of } \\
\text { items }\end{array}$ & $\begin{array}{l}\text { Sample } 2 \\
(n=408)\end{array}$ & $\begin{array}{c}\text { Sample 3b } \\
(n=57)\end{array}$ & Sample 4 & $\begin{array}{l}\text { Sample } 5 \\
(n=144)\end{array}$ & $\begin{array}{c}\text { Sample } 6 \\
(n=49)\end{array}$ & $\begin{array}{l}\text { Sample } 8 \\
(n=115)\end{array}$ & $\begin{array}{c}\text { Sample } 9 \\
(n=95)\end{array}$ & $\begin{array}{r}\text { Sample } 10 \\
(n=156)\end{array}$ \\
\hline \multicolumn{10}{|c|}{ Coefficient $\alpha$} \\
\hline $\begin{array}{l}\text { Political-economic conservatism } \\
\text { Protestant Work Ethic }\end{array}$ & $\begin{array}{r}3 \\
19\end{array}$ & $\begin{array}{l}.69 \\
.68 \\
.65\end{array}$ & $\begin{array}{l}.83 \\
.75\end{array}$ & $.89^{\mathrm{a}}$ & .80 & .71 & .80 & $\begin{array}{l}.72 \\
.73\end{array}$ & .78 \\
\hline $\begin{array}{l}\text { Just World } \\
\text { Nationalism }\end{array}$ & 20 & .55 & .42 & & & & & & \\
\hline $\begin{array}{l}\text { Nationalism } \\
\text { Patriotism }\end{array}$ & 6 & .75 & .88 & $.80^{\mathrm{a}}$ & .68 & .86 & .78 & .66 & .62 \\
\hline Patriotism & 12 & & & & .83 & .89 & & .80 & \\
\hline Cultural elitism & 7 & & & & .67 & .78 & & .59 & \\
\hline Equal opportunity & 6 & & & & .65 & .76 & & .49 & \\
\hline Noblesse oblige & 6 & .58 & .80 & $.69^{\mathrm{a}}$ & .68 & .73 & .56 & .72 & .54 \\
\hline Anti-Black racism & 5 & .68 & .77 & & .70 & .74 & .60 & .77 & \\
\hline \multicolumn{10}{|c|}{ Correlations } \\
\hline Political-economic conservatism & & $.26^{* *}$ & $.28^{*}$ & $.44^{* * b}$ & .11 & $.72^{* *}$ & $.24^{*}$ & $.17^{*}$ & $.55^{* *}$ \\
\hline $\begin{array}{l}\text { Protestant Work Ethic } \\
\text { Just World }\end{array}$ & & -.03 & $.33^{*}$ & & & & & .03 & \\
\hline $\begin{array}{l}\text { Just World } \\
\text { Nationalism }\end{array}$ & & .09 & $.43^{* *}$ & & & & & & \\
\hline $\begin{array}{l}\text { Nationalism } \\
\text { Patriotism }\end{array}$ & & $.52^{* *}$ & $.41^{* *}$ & $.53^{* * \mathrm{~b}}$ & $.43^{* *}$ & $.67^{* *}$ & $.51^{* *}$ & $.47^{* *}$ & $.72^{* *}$ \\
\hline $\begin{array}{l}\text { Patriotism } \\
\text { Cultural elitism }\end{array}$ & & & & & $.43^{* *}$ & $.65^{* *}$ & & $.22^{*}$ & \\
\hline $\begin{array}{l}\text { Cultural elitism } \\
\text { Equal opportunity }\end{array}$ & & & & & $.51^{* *}$ & .23 & & $.44^{* *}$ & \\
\hline Equal opportunity & & & & & $.51^{* * *}$ & $.51^{* *}$ & & $.34^{* *}$ & \\
\hline $\begin{array}{l}\text { Noblesse oblige } \\
\text { Anti-Black racism }\end{array}$ & & $-.39^{* *}$ & $-.54^{* *}$ & $-.43^{* * b}$ & $-.60^{* * *}$ & & $-.69^{* *}$ & $-.50^{* *}$ & $-.72^{* *}$ \\
\hline Anti-Black racism & & $.57^{* *}$ & $.42^{* *}$ & & $.49^{* *}$ & $.61^{* *}$ & $.65^{* *}$ & $.52^{* *}$ & \\
\hline
\end{tabular}

$\mathrm{a} n=180 . \mathrm{b}^{\mathrm{b}} \mathrm{n}=90$.

${ }^{*} p<.05$. ** $p<.01$.

der policies, military programs, gay rights, women's rights, social programs generally, racial policies, and environmental policies in most of our samples (see coefficient alphas in Table 5).

Support for chauvinist policies and law and order policies were positively correlated with SDO in almost all samples, averaging .34 and .28 , respectively. Support for military programs was positively correlated with SDO in all samples, averaging .44. Support for gay rights, women's rights, social welfare programs, ameliorative racial policy, miscegenation, and environmental policy were significantly negatively related to SDO in all but three cases (see Table 5). These relationships were of about the same magnitudes as the policy attitudes described above. We assessed political party preference by having subjects rate themselves from strong Democrat (1) through independent (4) to strong Republican (7) and others. Excluding “others," Republican political party preference correlated positively and sig- nificantly with SDO in six out of six samples, averaging .28 (see Table 5).

In addition to support for military programs, we expected support for military action including war to be positively related to SDO. We tested this hypothesis by surveying attitudes toward war in general and specific attitudes toward the war against Iraq fought by the United States and other nations at the time of data collection. In fall 1990, while Iraq was occupying Kuwait and the United States was amassing troops near Iraq, data from Sample 2 were collected, including a single war policy item, "Going to war to maintain low oil prices." This item correlated .30 with SDO $(p<.01)$. In January, 1991, when the United States and allies had just begun bombing Iraq, we administered a balanced scale concerning war and related attitudes to Sample 4. A reliable $(\alpha=.85)$ eight-item pro-war scale correlated .51 with SDO $(p<.01)$. One year later, we asked Sample 8 about

Table 4

Coefficient Alphas of Sexism Scales and Correlations With Social

Dominance Orientation Within Samples

\begin{tabular}{|c|c|c|c|c|c|}
\hline \multirow[b]{2}{*}{ Measure } & \multirow{2}{*}{$\begin{array}{l}\text { No. of } \\
\text { items }\end{array}$} & \multicolumn{2}{|c|}{ Coefficient $\alpha$} & \multicolumn{2}{|c|}{ Correlations } \\
\hline & & Sample 5 & Sample 6 & Sample 5 & Sample 6 \\
\hline Rombough \& Ventimiglia sexism & 20 & .90 & .94 & $.44^{* *}$ & $.54^{* *}$ \\
\hline Sex differences & 5 & .68 & .65 & $.38^{* *}$ & $.56^{* *}$ \\
\hline Internal (household) labor & 10 & .89 & .94 & $.34^{* *}$ & $.63^{* *}$ \\
\hline External (paid) labor & 6 & .78 & .85 & $.45^{* *}$ & $.36^{*}$ \\
\hline Sexist Attitudes Toward Women & 40 & .91 & .94 & $.46^{* *}$ & $.55^{* *}$ \\
\hline Rape Myths & 10 & .84 & .75 & $.46^{* *}$ & $.40^{* *}$ \\
\hline
\end{tabular}

$* p<.05 . \quad * * p<.01$. 
Table 5

Coefficient Alphas of Policy Scales, Correlations With Social Dominance Orientation, and Partial Correlations Controlling for Conservatism, Across Samples

\begin{tabular}{|c|c|c|c|c|c|c|c|c|}
\hline \multirow[b]{2}{*}{ Policy scale } & \multirow[b]{2}{*}{$\begin{array}{l}\text { No. of } \\
\text { items }\end{array}$} & \multicolumn{7}{|c|}{ Sample } \\
\hline & & $\begin{array}{c}2 \\
(n=455)\end{array}$ & $\begin{array}{c}3 \mathrm{~b} \\
(n=50)\end{array}$ & 4 & $\begin{array}{c}5 \\
(n=129)\end{array}$ & $\begin{array}{c}6 \\
(n=37)\end{array}$ & $\begin{array}{c}8 \\
(n=100)\end{array}$ & $\begin{array}{c}9 \\
(n=89)\end{array}$ \\
\hline \multicolumn{9}{|c|}{ Coefficient $\alpha$} \\
\hline Chauvinism & 8 & & & .73 & & .73 & & .58 \\
\hline Law and order & 4 & .64 & .71 & & .59 & $.77^{\mathrm{a}}$ & .67 & $.77^{\mathrm{b}}$ \\
\hline Military programs & 3 & $.67^{\mathrm{a}}$ & .75 & & .73 & .67 & & .59 \\
\hline Gay \& lesbian rights & 2 & .82 & .91 & & .85 & .86 & & .83 \\
\hline Women's rights & 4 & .63 & .72 & & .69 & .63 & $.80^{\mathrm{c}}$ & .74 \\
\hline Social programs & 10 & .78 & .77 & & .79 & .86 & $.66^{\mathrm{c}}$ & $.8 \mathrm{I}^{\mathrm{d}}$ \\
\hline Racial policy & 7 & .71 & .81 & & .68 & .72 & $.60^{c}$ & .77 \\
\hline Miscegeny & 2 & .96 & .97 & & .93 & .94 & .91 & .87 \\
\hline \multirow{2}{*}{$\begin{array}{l}\text { Environmental } \\
\text { policies }\end{array}$} & & & & & & & & \\
\hline & 5 & & & & .71 & .80 & & .76 \\
\hline
\end{tabular}

Correlations of social dominance orientation and policy items

\begin{tabular}{|c|c|c|c|c|c|c|}
\hline Chauvinism & & & $.37^{* *}$ & $.49^{* *}$ & & .14 \\
\hline Law and order & .08 & $.23^{*}$ & $.30^{* *}$ & $.59^{* *}$ & $.24^{*}$ & .19 \\
\hline Military programs & $.33^{* *}$ & $.27^{*}$ & $.33^{* *}$ & $.70^{* *}$ & & $.47^{* *}$ \\
\hline Gay \& lesbian rights & $-.32 * *$ & $-.50^{* *}$ & $-.29^{* *}$ & $-.55^{* *}$ & & -.17 \\
\hline Women's rights & $-.42^{* *}$ & $-.32^{* *}$ & $-.39 * *$ & $-.34^{*}$ & $-.52^{* *}$ & $-.42^{* *}$ \\
\hline Social programs & $-.50^{* *}$ & $-.31^{* *}$ & $-.29^{* *}$ & $-.70^{* *}$ & $-.55^{* *}$ & $-.39 * *$ \\
\hline Racial policy & $-.42^{* *}$ & $-.46^{* *}$ & $-.23^{* *}$ & $-.62^{* *}$ & $-.54 * *$ & $-.34^{* *}$ \\
\hline Miscegeny & $-.31^{* *}$ & -.15 & $-.30^{* *}$ & $-.31^{*}$ & $-.25^{*}$ & -.18 \\
\hline $\begin{array}{l}\text { Environmental } \\
\text { policies }\end{array}$ & & & $-.27^{* *}$ & $-.40^{* *}$ & & $-.47^{* *}$ \\
\hline preference & $.15^{* *}$ & $.25^{*}$ & $.24^{* *}$ & $.45^{* *}$ & $.33^{* *}$ & $.27^{*}$ \\
\hline
\end{tabular}

Partial correlations removing political-economic conservatism

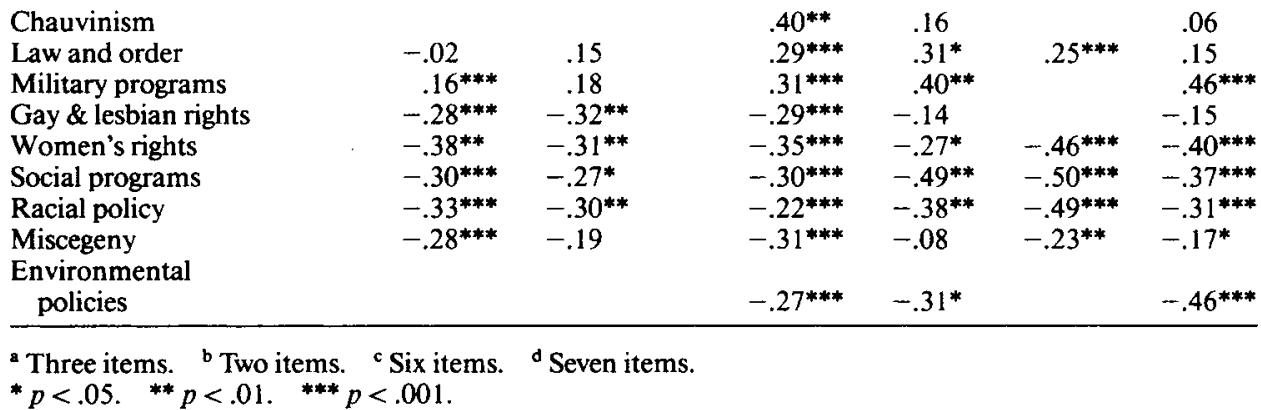

their attitudes toward the Iraq war. The resulting Iraq War Attitudes scale was reliable $(\alpha=.85)$ and correlated .29 with SDO $(p<.01)$.

Does SDO, then, unconditionally predict support for war, or only war for certain purposes? We attempted to answer this question by designing a General War Attitudes scale including two kinds of items, namely, Wars of Dominance, which we expected to relate positively to SDO, and Wars for Humanitarian Reasons, which we did not expect to relate positively to SDO. This scale was administered to Sample 8 in January, 1992. Factor analysis confirmed that these were two independent dimensions. The Wars of Dominance scale (eight items) was reliable $(\alpha=.82)$ and correlated positively with $\operatorname{SDO}(r=.31, p<.01)$. The Humanitarian Wars scale (six items) ${ }^{3}$ was also reliable $(\alpha=$ $.73)$ and correlated negatively with SDO $(r=-.41, p<.01)$, so
SDO is not merely antipacifism. The Wars of Dominance scale was positively correlated with support for the Iraq war $(r=.63$, $p<.001$ ), but the Humanitarian Wars scale was uncorrelated with support for the Iraq war $(r=.07)$. These results suggest that SDO does not predict support for war unconditionally; rather, SDO predisposes people to endorse group dominance ideologies, thus facilitating support for wars of dominance.

\section{Discriminant Validity}

We expected SDO to correlate with political-economic conservatism, and indeed it did. However, to show that SDO has

\footnotetext{
${ }^{3}$ Two unreliable items were eliminated from the scale.
} 
utility as a predictor of policy attitudes over and above politicaleconomic conservatism, we computed the correlations between SDO and the policy attitudes reported above after partialing out political-economic conservatism. Of the 41 significant zero-order correlations between SDO and policy attitudes in Table 5, only 5 become nonsignificant when political-economic conservatism is partialed out. ${ }^{4} \mathrm{~A}$ few of the very high zero-order correlations were reduced substantially, but many more partial correlations were almost the same as the zero-order correlations (see Table 5). Across all the samples, then, there was no consistent evidence that political-economic conservatism could replace SDO as a predictor of the policy attitudes we assessed.

In Sample 9, we assessed another rival predictor of policy attitudes, namely authoritarianism, using two measures. Altemeyer's 30-item RWA scale had good internal reliability $(\alpha=$ .78); Goertzel's measure was adequate for a bipolar scale ( $\alpha=$ .53). Both measures of authoritarianism correlated with political-economic conservatism $(r=.31$ for RWA, $r=.29$ for the Goertzel measure, both $p s<.01$ ), confirming their validity. Neither, however, correlated strongly with SDO. RWA correlated $.14(n s)$ with SDO, and the Goertzel measure correlated .18 with SDO $(p<.10)$. Correcting these correlations for attenuation yielded slightly higher correlations $\left(r^{*}=.18, p<.05\right.$ for RWA; $r^{*}=.28, p<.01$ for the Goertzel measure).

We also computed partial correlations between SDO and the policy attitudes, partialing the two authoritarianism measures and political-economic conservatism. In Sample 9, all the policies that showed significant zero-order correlations with SDO also had significant correlations with SDO, partialing out the effects of political-economic conservatism, RWA, and the Goertzel measure. Both authoritarianism measures showed substantial zero-order correlations with attitudes that were not as highly correlated with SDO in this sample: gay rights ( $r=$ -.51 for RWA, $r=-.31$ for the Goertzel measure, $p \mathrm{~s}<.01)$ and chauvinistic policies $(r=.38$ for RWA, $p<.01, r=.25$ for the Goertzel measure, $p<.05$ ). As Peterson, Doty, and Winter (1993) showed recently, authoritarianism still predicts social attitudes, particularly those relevant to untraditional sexual practices and prejudice against foreigners.

Because authoritarian personality theory (Adorno et al., 1950) also postulates that authoritarianism should predict ethnocentrism, racism, nationalism, and conservatism, we tested whether SDO would still predict belief in these legitimizing myths, controlling for authoritarianism. All the reliable zeroorder correlations between SDO and ideological measures were reliable after controlling for RWA and the Goertzel measure, except for the correlation with political-economic conservatism. The correlation between SDO and political-economic conservatism, partialing RWA, was $.13(p=.11)$. Partialing the Goertzel measure, the correlation between SDO and politicaleconomic conservatism was $.16(p=.07)$, and partialing both measures, the correlation was $.13(p=.11)$. Although the relationship between SDO and conservatism may be explained by their joint relationship to authoritarianism, the relationships between SDO and racism and nationalism cannot.

\section{Dominance and Self-Esteem}

Conservatism and authoritarianism were the only rival variables we identified as predictors of social and political attitudes, and the analyses above show that SDO substantially related to such attitudes, even when controlling for political-economic conservatism and for authoritarianism. To show a different kind of discriminant validity, we tested whether SDO correlated with other personality measures. If any of these were large, we would then be obliged to test the partial correlations with the social and political attitudes discussed above.

Only once did SDO correlate with the CPI and JPRF Dominance subscales across five samples (see Table 6). On average, CPI Dominance correlated .03 with SDO, and JPRF Dominance correlated -.006 . These results clearly indicate that SDO is independent of interpersonal dominance. In Sample 1, SDO was also unrelated to CPI Flexibility $(r=.06)$ and Capacity for Status $(r=.05)$. For the most part, SDO was also uncorrelated with self-esteem in Samples 1 through 9, averaging -.08 (see Table 6).

\section{Other Personality Measures}

We used data collected by other researchers at Stanford during mass testing sessions to further investigate the discriminant validity of SDO. SDO was uncorrelated with all the self-monitoring and self-consciousness scales in Sample 11. In Samples $7,9,11$, and 12 , SDO correlated $-.06,-.11, .08$, and -.19 , respectively, with Extraversion; none of these correlations differed reliably from zero. SDO correlated -.02, .13, - .08, and .21 in those samples, respectively, with Neuroticism; none of these differed reliably from zero. SDO correlated -.03 with Agreeableness in Sample 7 and $-.41(p<.01)$ in Sample 9. SDO correlated -.04 and - .14 with Conscientiousness in Samples 7 and 9, neither of which differed reliably from zero. SDO correlated -.28 with Openness $(p<.01)$ in Sample 9. These data do not suggest that SDO is redundant with any of the BigFive dimensions and strongly imply that SDO is independent of Extraversion and Neuroticism. Across this set of correlations, there was also no evidence that SDO is related to the positively valued personality dimensions (e.g., Extraversion and Calmness) as opposed to the negative dimensions (e.g., Introversion and Neuroticism).

\section{Convergent Validity}

\section{Empathy, Altruism, and Communality}

We expected that feelings of closeness and kindness toward others should mitigate desire to dominate other groups, so empathy, altruism, and communality should correlate negatively with SDO. We first tested whether different varieties of empathy were negatively related to SDO using Davis' (1983) IRI. The Concern for Others subscale was significantly negatively correlated with SDO in every sample ( $r$ ranged from -.40 to -.53 and averaged -.46; see Table 7). High dominance-oriented people expressed less concern for others than did low dominanceoriented people. The patterns of correlations between SDO and the other subscales were not as consistent across samples, but when they were significant, all correlations were negative (see Table 7). The total Empathy scale was negatively correlated

\footnotetext{
${ }^{4}$ One other correlation actually became significant because partial correlations use one-tailed tests.
} 
Table 6

Coefficient Alphas of Interpersonal Dominance and Self-Esteem and Correlations

With Social Dominance Orientation Within Samples

\begin{tabular}{|c|c|c|c|c|c|c|c|c|c|c|}
\hline \multirow[b]{2}{*}{ Measure } & \multirow[b]{2}{*}{$\begin{array}{l}\text { No. of } \\
\text { items }\end{array}$} & \multicolumn{9}{|c|}{ Sample } \\
\hline & & $\begin{array}{c}1 \\
(n=98)\end{array}$ & $\begin{array}{c}2 \\
(n=403)\end{array}$ & $\begin{array}{c}3 \mathrm{a} \\
(n=80)\end{array}$ & $\begin{array}{c}3 \mathrm{~b} \\
(n=57)\end{array}$ & $\begin{array}{c}4 \\
(n=90)\end{array}$ & $\begin{array}{c}5 \\
(n=144)\end{array}$ & $\begin{array}{c}6 \\
(n=56)\end{array}$ & $\begin{array}{c}8 \\
(n=115)\end{array}$ & $\begin{array}{c}9 \\
(n=95)\end{array}$ \\
\hline \multicolumn{11}{|c|}{ Coefficient $\alpha$} \\
\hline CPI Dominance & 35 & .82 & .79 & & .79 & & & & .71 & .71 \\
\hline JPRF Dominance & 19 & .81 & .81 & & .74 & & & & .73 & .69 \\
\hline Rosenberg Self-Esteem & 10 & .87 & .87 & .88 & .88 & .90 & .87 & .85 & .84 & .83 \\
\hline \multicolumn{11}{|c|}{ Correlations } \\
\hline CPI Dominance & & -.11 & -.03 & & -.17 & & & & $.24^{* *}$ & .20 \\
\hline JPRF Dominance & & -.04 & $.13^{* *}$ & & -.17 & & & & .01 & .04 \\
\hline Rosenberg Self-Esteem & & -.09 & -.18 & .09 & .01 & .16 & $-.23^{* *}$ & -.01 & $-.29^{* *}$ & $-.14^{*}$ \\
\hline
\end{tabular}

Note. $\quad \mathrm{CPI}=$ California Psychological Inventory; JPRF $=$ Jackson Personality Research Form.

${ }^{*} p<.05 .{ }^{* *} p<.01$.

with SDO in 5 of 6 samples (averaging $r=-.31$ ), but not as highly as the Concern for Others subscale. We conclude that concern for others is the form of empathy that precludes the desire to dominate other groups.

As one might expect, altruism was correlated with the Concern for Others subscale in Samples 5 and 6 ( $p s<.001)$ and was negatively correlated with SDO (see Table 7). Communality was also negatively correlated with SDO in Samples 8 and 9 (see Table 7). In addition, Katz and Hass' (1988) 10-item Humanitarian-Egalitarian Scale correlated negatively with SDO $(\alpha=$
$.80, r=-.34, p<.01$ ) in Sample 9; this scale includes altruistic, inclusive, and egalitarian items.

The constellation of qualities including communality, emotional empathy, and altruism has been termed "linking" and is stereotypically associated with the female sex (e.g., Eisler \& Loye, 1983). However, it is important to note that SDO's correlations with communality, altruism, and concern for others were significant even after controlling for sex. Thus, gender differences alone are not responsible for the correlations between SDO and communality, altruism, and concern for others.

Table 7

Coefficient Alphas of Empathy, Altruism, and PAQ Subscales and Correlations With Social Dominance Orientation

\begin{tabular}{|c|c|c|c|c|c|c|c|}
\hline \multirow[b]{2}{*}{ Measure } & \multirow[b]{2}{*}{$\begin{array}{l}\text { No. of } \\
\text { items }\end{array}$} & \multicolumn{6}{|c|}{ Sample } \\
\hline & & $\begin{array}{l}\text { Sample } 2 \\
(n=403)\end{array}$ & $\begin{array}{c}\text { Sample 3b } \\
(n=57)\end{array}$ & $\begin{array}{l}\text { Sample 5 } \\
(n=144)\end{array}$ & $\begin{array}{c}\text { Sample } 6 \\
(n=56)\end{array}$ & $\begin{array}{l}\text { Sample } 8 \\
(n=115)\end{array}$ & $\begin{array}{c}\text { Sample } 9 \\
(n=95)\end{array}$ \\
\hline \multicolumn{8}{|c|}{ Coefficient $\alpha$} \\
\hline $\begin{array}{l}\text { Empathy } \\
\text { Concern } \\
\text { Distress } \\
\text { Perspective-taking } \\
\text { Fantasy } \\
\text { Altruism } \\
\text { PAQ Communality } \\
\text { PAQ Agency } \\
\end{array}$ & $\begin{array}{r}28 \\
7 \\
7 \\
7 \\
7 \\
5 \\
23 \\
28 \\
\end{array}$ & $\begin{array}{l}.76 \\
.73 \\
.71 \\
.64 \\
.71\end{array}$ & $\begin{array}{l}.72 \\
.77 \\
.70 \\
.78 \\
.79\end{array}$ & $\begin{array}{l}.77 \\
.66 \\
.67 \\
.74 \\
.70 \\
.87\end{array}$ & $\begin{array}{l}.75 \\
.75 \\
.74 \\
.84 \\
.72 \\
.87\end{array}$ & $\begin{array}{l}.75 \\
.69 \\
.61 \\
.71 \\
.70 \\
.76 \\
.80\end{array}$ & $\begin{array}{l}.73 \\
.68 \\
.52 \\
.58 \\
.64 \\
\\
.78 \\
.80 \\
\end{array}$ \\
\hline \multicolumn{8}{|c|}{ Correlations } \\
\hline $\begin{array}{l}\text { Empathy } \\
\text { Concern } \\
\text { Distress } \\
\text { Perspective-taking } \\
\text { Fantasy } \\
\text { Altruism } \\
\text { PAQ Communality } \\
\text { PAQ Agency }\end{array}$ & & $\begin{array}{l}-.40^{* *} \\
-.45^{* *} \\
-.03 \\
-.30^{* *} \\
-.23^{* *}\end{array}$ & $\begin{array}{l}-.21 \\
-.51^{* *} \\
-.11 \\
.05 \\
.01\end{array}$ & $\begin{array}{l}-.26^{* *} \\
-.47^{* *} \\
.10 \\
-.20^{*} \\
-.06 \\
-.32^{* *}\end{array}$ & $\begin{array}{l}-.36^{*} \\
-.41^{* *} \\
-.16 \\
-.16 \\
-.25^{*} \\
-.24^{*}\end{array}$ & $\begin{array}{l}-.38^{* *} \\
-.53^{* *} \\
.22^{* *} \\
-.39^{* *} \\
-.21^{*} \\
-.42^{* *} \\
-.10\end{array}$ & $\begin{array}{l}-.24^{*} \\
-.40^{* *} \\
.21^{*} \\
-.15 \\
-.23^{*} \\
-.24^{*} \\
-.08\end{array}$ \\
\hline
\end{tabular}

Note. $\mathrm{PAQ}=$ Personal Attributes Questionnaire.

${ }^{*} p<.05 .^{* *} p<.01$. 
Lest high levels of dominance orientation be confused with agency, it is important to emphasize that there was no correlation between SDO and the PAQ Agency scale in Samples 8 and 9 (see Table 7).

\section{Tolerance}

SDO was negatively related to the JPI Tolerance subscale ( $r \mathrm{~s}$ $=-.27,-.36$, and -.27 , all $p s<.01$ in Samples 1, 8, and 9, respectively), despite the low reliabilities of the Tolerance subscale, which has a true-false response format $(.53,5.59$, and .18 , respectively). When corrected for attenuation, the correlations were $-.40,-.52$, and -.71 , respectively $(p s<.001)$, but these may be considered "overcorrected" because of the low reliability coefficients of the Tolerance scale. The average correlation between SDO and Tolerance was -.30 .

\section{SDO as an Orientation: Predicting New Attitudes}

According to social dominance theory, one of SDO's most significant functions is orienting people toward or away from new social attitudes. Therefore, we tested whether SDO predicted beliefs in new legitimizing myths and support for new policies. Unfolding public events provided three opportunities to test attitudes toward "new" policies, some of which had rather novel legitimizations provided for them.

\section{Iraq War}

War making is an extreme act of discrimination against an out-group; enemy out-group members are routinely starved, raped, killed, maimed, or made ill during war. Given that, we expect that arguments given in support of war would serve as legitimizing myths and thus should relate to SDO. We tested this hypothesis looking at U.S. policy in the aftermath of the Iraqi invasion of Kuwait in 1990. Pundits seemed to feel the White House gave several different reasons for U.S. policy at the time, so this was an opportune occasion to examine the operation of new legitimizing myths. National random-sample opinion polls showed significant fluidity of attitudes about appropriate policy up until the United States began bombing Iraq on January 16, 1991. For example, the Los Angeles Times poll showed that merely $38 \%$ of the public favored going to war against Iraq on November 14, 1990, but that once U.S. troops had begun bombing, $81 \%$ of the public on January 17-18, 1991, and on February 15-17, 1991, approved of the war. Even just before and after the bombing began, there were dramatic shifts in opinion; from January 8-12, 1991, 39\% felt that economic sanctions against Iraq should be used without resorting to war, but on January 17-18, 1991, 72\% of the public believed President Bush had given enough time for economic sanctions to work. The outcome of the present study was, then, by no means certain.

During the third week of January, 1991, subjects in Sample 4 completed an Iraq War Attitudes survey. We asked subjects how willing they would be to make sacrifices for war (as opposed to making sacrifices to prevent wars), whether they favored suspending certain civil liberties and invoking the draft during war, and whether they favored military action against Iraq. We also measured a new "legitimizing myth," namely, that Iraq should be stopped because of the environmental damage that it was inflicting on the Gulf. This idea was brought up because the Iraqi leader, Saddam Hussein, had threatened to burn all of Kuwait's oil if Iraq was bombed, and the recent 20th anniversary of Earth Day had put environmental concerns on the public's mind. SDO was positively and significantly correlated with each of these attitude dimensions (see Table 8). Higher SDO levels were associated with favoring military action against Iraq, favoring suspension of civil liberties for the war, a willingness to make sacrifices for the war effort, and a nationalistic view of environmental problems associated with the war.

\section{Clarence Thomas' Nomination to the Supreme Court}

Political appointments can also be considered policies that have implications for intergroup relations, and also can be legitimized; therefore, their relationship to SDO is of theoretical concern. The second new attitude that we assessed was support for Clarence Thomas' appointment to the Supreme Court. This appointment was related to a number of long-standing legitimizing myths, including conservatism, meritocracy, racism, and sexism, shown above to relate to SDO. Thomas, widely considered a Black conservative, was nominated to replace Thurgood Marshall, a Black former civil rights lawyer, who announced his intention to retire. President Bush nominated Thomas to the Supreme Court in the spring of 1991, and the Senate Judiciary Committee held hearings on this nomination in the spring and fall. Just before the vote to confirm Thomas was scheduled, a news story broke that two of Thomas' former subordinates had accused him of sexual harassment. One of these persons, Anita Hill, was called to testify before the Judiciary Committee, and the proceedings received much publicity including gavel-to-gavel television and radio coverage. After an entire weekend of testimony solely about the sexual harassment charge, the Judiciary Committee voted to confirm Thomas on October $15,1991 .^{6}$

We telephoned 149 of the $173(86 \%)$ subjects in Sample 7 (who had completed the SDO scale in late September) on that day or on the following 2 days and asked them four attitudinal questions about Thomas and Hill. They responded to statements on 7-point scales where 1 meant strongly disagree and 7 meant strongly agree. The statements were (a) "after Thurgood Marshall's retirement from the Supreme Court, it was good that George Bush appointed a Black person to the Court," (b) "after Thurgood Marshall's retirement from the Supreme Court, it was good that George Bush appointed a conservative to the Court," (c) "If I were in the Senate, I would have voted in favor of Clarence Thomas' confirmation to the Supreme Court," and (d) "Anita Hill was telling the truth in claiming that Clarence Thomas sexually harassed her." We found that SDO significantly predicted opposition to nominating a Black to the Supreme Court, support for nominating a conservative to the court, support for Clarence Thomas, and disbelief of Anita Hill's testimony (see correlations in Table 8).

\footnotetext{
${ }^{5}$ By accident, only the 10 false-coded items in the scale were administered to Sample 1 .

${ }^{6}$ Because of the time delay between Washington, DC, and California, Californians heard this news as they awoke.
} 
Table 8

Coefficient Alphas and Correlations of Social Dominance Orientation With New Attitudes

\begin{tabular}{lccc}
\hline \multicolumn{1}{c}{ Scale or item } & $\begin{array}{c}\text { No. of } \\
\text { items }\end{array}$ & $\begin{array}{c}\text { Coefficient } \\
\alpha\end{array}$ & $\begin{array}{c}\text { Correlation with } \\
\text { social dominance } \\
\text { orientation }\end{array}$ \\
\hline & Sample 4 & & \\
Favors military action by U.S. & 5 & .78 & $.48^{* *}$ \\
Willing to make sacrifices for war & 4 & .56 & $.45^{* *}$ \\
Favors suspending liberties for war & 4 & .51 & $.45^{* *}$ \\
Concerned about environment in war & 4 & .57 & $.28^{* *}$ \\
\hline
\end{tabular}

Sample 7

\begin{tabular}{lc} 
Favors appointing a Black person & $-.20^{*}$ \\
Favors appointing a conservative & $.32^{* * *}$ \\
Favored Clarence Thomas' confirmation & $.22^{* *}$ \\
Believed Anita Hill's testimony & $-.26^{* * *}$ \\
\hline
\end{tabular}

Sample 10

\begin{tabular}{llll} 
Specific deterrence & 3 & .70 & $.35^{* *}$ \\
Favored executing Harris & 2 & .96 & $.36^{* *}$ \\
Painful executions & 8 & .86 & $.42^{* *}$ \\
Belief in retribution & 5 & .74 & $.51^{* *}$ \\
\hline
\end{tabular}

${ }^{*} p<.05 . \quad{ }^{* *} p<.01 . \quad{ }^{* * *} p<.001$.

\section{Death Penalty}

Elsewhere, we have argued that SDO should also be related to support of legal institutions that are discriminatory or inegalitarian in their effects (Sidanius, 1993; Sidanius, Liu, Pratto, \& Shaw, 1994). Mitchell (1993) showed that SDO is related to ideologies that legitimize the use of the death penalty, such as the belief in legal retribution or the belief that the death penalty has a deterrent effect on crime. We assessed SDO in March, 1992, in Sample 10; 2 weeks later, we administered an extensive survey about death penalty ideologies and about the execution of Robert Alton Harris, who was executed by the state of California the day before the subjects were surveyed. Belief that executions have a specific deterrent effect, support for Harris' execution, support of painful executions, and belief in retribution were positively correlated with SDO (see Table 8).

\section{Summary}

To provide a summary of the correlations with SDO, we used Fisher's $z$-to- $r$ formula to average the correlations across samples (e.g., Rosenthal, 1986, p. 27). To test the average statistical significance of the correlation coefficients, we computed standard normal $(Z)$ scores corresponding to each correlation coefficient using the large-sample formula $Z=r \times(N)^{1 / 2}$. The total of the $Z$ scores across samples divided by the square root of the number of samples can be compared with the standard normal distribution to test the null hypothesis that the pattern of correlations obtained over samples occurred because of chance associations between SDO and the variable in question. ${ }^{7}$

On average, subject sex correlated .26 with $\mathrm{SDO}(Z=9.92, p$ $<.001)$. Thus, the data were consistent with our prediction that men will be higher on SDO than women.

In terms of discriminant validity, over five samples, the aver- age correlation between SDO and CPI Dominance was .03 and the average correlation between SDO and JPRF Dominance was - .01. Over nine samples, the average correlation between SDO and RSE was - .08. Averaged over four samples, SDO correlated -.03 with Extraversion and .10 with Neuroticism. Clearly SDO is independent of all of these constructs. As expected, SDO had moderate negative correlations with concern for others, communality, tolerance, and altruism (see average correlations in Table 9). The averaged correlations were clearly different from zero, but they were not high enough that they indicate redundancy between these measures and SDO either, given that they ranged from -.28 for altruism to -.46 for concern for others.

SDO strongly and consistently related to belief in a number of hierarchy-legitimizing myths, most strongly to anti-Black racism and nationalism. SDO also was strongly negatively related to a hierarchy-attenuating ideology, noblesse oblige. SDO correlated consistently positively with beliefs in sexism, equal opportunities, patriotism, cultural elitism, conservatism, and a Just World. The Protestant Work Ethic was the only legitimizing ideology that we did not find to relate to SDO reliably over samples (see Table 9).

Finally, SDO showed strong consistent correlations with scales assessing opposition to social programs, racial policies, and women's rights, and with support for military programs. SDO was also consistently correlated with opposition to gay and lesbian rights, environmental programs, and miscegeny and was consistently correlated with support for U.S. chauvinism, law-and-order policies, and Republican party identification (see Table 9). SDO also predicted attitudes toward new political

\footnotetext{
${ }^{7}$ A $Z$ statistic with smaller variance could also have been computed by using the sample variance to weight the $Z$ from each sample, which would cause all the $p$ values given below to be smaller.
} 
Table 9

Average Correlations and Significance Tests Across Samples Between Social Dominance Orientation and Personality Variables, Ideologies, and Policy Attitudes

\begin{tabular}{lrrr}
\hline \multicolumn{1}{r}{ Measure } & Mean $r$ & $n$ & $Z$ \\
\hline & Personality variables & & \\
Concern for others & -.46 & 6 & -8.92 \\
Communality & -.33 & 2 & -4.84 \\
Tolerance & -.30 & 3 & -5.31 \\
Altruism & -.28 & 2 & -3.98 \\
\hline
\end{tabular}

Ideologies

\begin{tabular}{lrrr} 
Anti-Black racism & .55 & 6 & 15.05 \\
Noblesse oblige & -.57 & 10 & 20.30 \\
Nationalism & .54 & 8 & 15.96 \\
Sexism & .47 & 12 & 14.91 \\
Equal opportunities & .46 & 3 & 7.51 \\
Patriotism & .45 & 3 & 6.84 \\
Cultural elitism & .40 & 3 & 6.94 \\
Political-economic conservatism & .38 & 8 & 10.26 \\
Just World & .27 & 2 & 3.58 \\
Protestant Work Ethic & .11 & 3 & 1.25 \\
\hline
\end{tabular}

Policy attitudes

\begin{tabular}{lrrr} 
Social programs & -.47 & 6 & -12.74 \\
Racial policy & -.44 & 6 & -11.74 \\
Women's rights & -.40 & 6 & -11.52 \\
Military programs & .44 & 5 & -10.12 \\
Gay \& lesbian rights & -.37 & 5 & -8.79 \\
Environmental programs & -.38 & 3 & -6.16 \\
Chauvinism & .34 & 3 & 5.34 \\
Miscegeny & -.25 & 6 & -7.36 \\
Republican party preference & .28 & 6 & 7.08 \\
Law and order & .28 & 6 & 6.38 \\
\hline
\end{tabular}

Note. All Zs were significant at $p<.0001$ except for Just World ( $p=$ $.0002)$ and Protestant Work Ethic $(p=.10)$. The mean $r$ was computed using Fisher's $z ; n$ denotes number of samples.

events, including the 1991 war against Iraq, Clarence Thomas as a Supreme Court Justice, and a state execution. Those aspiring to hierarchy-enhancing careers had higher SDO scores than those aspiring to hierarchy-attenuating careers. Thus, we have provided substantial evidence that SDO (a) can be measured reliably, (b) is stable over time, (c) is higher among men than among women, (d) is higher among those who support hierarchy-enhancing ideologies and is lower among those who support hierarchy-attenuating ideologies, (e) is higher among those who support hierarchy-enhancing policies and lower among those who support hierarchy-attenuating policies, (f) is higher among those who choose hierarchy-enhancing social roles and lower among those who choose hierarchy-attenuating social roles, and (g) serves to orient new social and political attitudes.

\section{DISCUSSION}

On the basis of social dominance theory, we postulated that there is an important individual difference in general preference for group domination, which we call social dominance orientation. As its definition and name implies, SDO may best be considered a general social-attitudinal orientation or implicit value relevant to intergroup relations. Some of our data inform us that there may be a significant relationship between one's orientation toward other persons in general and one's orientation toward other groups. People who are highly empathic (specifically, concerned with others' well-being) and to a lesser extent, those who feel interdependent or communal with others, tend to prefer egalitarian relationships among groups. Given that SDO predisposes people to believe in legitimizing myths and discriminatory policies, this would seem to make them less likely to believe in ideologies that relegate certain persons to "inferior" categories and to policies that disadvantage certain groups systematically. The recent work being done on interdependence (e.g., Depret \& Fiske, 1993; Markus \& Kitayama, 1991) may end up being quite informative about how to mitigate intergroup discrimination.

We might note that we came to postulate the existence of SDO not by thinking about "personality" in the traditional, individualistic sense, but by thinking about how group-based human social life is and the considerable data generated by researchers of political attitudes. We consider individual differences on SDO to be important not for showing the uniqueness of each person, nor for enabling us to classify persons into taxonomies. Rather, our finding of individual variation on SDO is central to our postulation of a dynamic model of human oppression in which different kinds of people (e.g., with high or low SDO) play different roles (e.g., enhance or attenuate inequality) and have different effects on each other (e.g., in how much they discriminate in the allocation of resources).

Despite significant variations in the degree of oppression from one society to another, it seems to us that many societies share the basic social-psychological elements that contribute to inequality: socially shared myths that define "superior group" and "inferior group" and that attempt to justify this distinction and the policies that "should" follow from it. As such, we postulate that individual variation on SDO could be reliably measured in many other societies and would show the same pattern of relationships to ideologies, policy attitudes, and hierarchy role as those shown here. Some of our previous research showed that group-dominance orientation significantly correlated with support for military programs, capitalism (Sidanius \& Pratto, 1993b), racism, and sexism (Sidanius, Devereux, \& Pratto, 1992; Sidanius \& Pratto, 1993a) in Sweden, a much more egalitarian country than the United States, and showed the same gender difference in Australia, Sweden, Russia, and the United States (see Sidanius, Pratto, \& Brief, 1993). In the future, we hope to examine whether SDO relates to rather different kinds of legitimizing myths that exist in very different cultural contexts, such as anti-Semitism in Poland, xenophobia in Japan, or fatalism in China.

Another kind of research endeavor that could further show the dynamic link between SDO and societal oppression would use SDO to predict attitudes toward new ideologies or policies. We expect that even when societies undergo substantial change, as with mass migration, technological innovation, or dramatic changes in borders or political leadership, such changes will be accepted only to the extent that they are satisfactorily legitimized and meet the public's level of desire for social dominance. Hence, the operation of SDO in the invention of new legitimizations and processes that assort persons into hierarchy roles may inform studies of political and social change. 


\section{SDO and Social Class}

Several political psychologists and sociologists have postulated or investigated the relationship between social class and conservatism, racism, or authoritarianism, with Lipset (1960) postulating that the working class is more authoritarian, and Stacey and Green $(1968,1971)$ and many others presenting evidence to the contrary. We have made no predictions concerning whether SDO should be correlated with social class in either direction; instead we suspect that SDO's relationship to these variables may vary as a function of hierarchy-group membership, which in some societies would be designated by class and in others by racial group, caste, and so forth. We tested for correlations between SDO and class in the present samples, and we found no statistically significant relationships between SDO and respondents' social class or family income category. Although there was substantial heterogeneity in these samples on these variables for the respondents' families of origin, the education level in these samples is clearly restricted. In contrast, in a random survey of the Los Angeles area, Sidanius et al. (in press) found statistically significant and monotonic decreases in scores from an abbreviated SDO scale with increasing family income level and increasing respondent's education level. With the data now in hand, we cannot say whether social classes differ on SDO.

\section{Authoritarianism Reconsidered}

In the sample in which we assessed SDO and authoritarianism, the correlations between two measures of authoritarianism and SDO were weak. However, because SDO predicts many of the social attitudes conceptually associated with authoritarianism (e.g., ethnocentrism, punitiveness, and conservatism), a more thorough comparison of these constructs is warranted. To begin with, there is little theoretical consensus on the construct of authoritarianism. The original and some contemporary researchers have described authoritarianism as a multifaceted construct; for example, Heaven (1985) suggested that authoritarianism is part achievement motivation, part dominance, part conventionalism, part militarism, part punitiveness, and part ethnocentrism. Although we think that the tendency for these constructs to covary is extremely important, calling this compendium authoritarianism is conceptually unsatisfying. It is neither a clear definition of a unitary construct nor a theory of why the separate constructs covary. In our view, punitiveness, ethnocentrism, conservatism, and sometimes conventionalism can function as legitimizing myths. Because legitimizing myths tend to be correlated with SDO, they are often spuriously correlated with one another. Thus, it is entirely possible that SDO underlies these correlations. By separately defining the presumably causative value orientation (SDO) and ideological stances (legitimizing myths and policy attitudes) and using distinct measures of the constructs, we have avoided the conceptual problem of describing an individual tendency as a set of correlations (see also Duckitt, 1989).

Other definitions of authoritarianism have avoided the compendium problem by radically restricting the meaning of the term. Ray (1976) postulated that part of authoritarianism is leadership desire or directiveness. That SDO did not significantly correlate with two robust measures of interpersonal dominance or with CPI Capacity for Status or PAQ Agency suggests that SDO cannot be interpreted as leadership desire. On this dimension, SDO and authoritarianism are distinct.

There is a new view of authoritarianism that we see as complementary to SDO, namely, Duckitt's (1989) description of authoritarianism as the desire for individuals to submit to authority figures within the in-group. The three classical dimensions of authoritarianism that covary empirically-submitting to in-group conventions, submitting to in-group authorities, and desiring to punish members who do not submit to in-group norms and authorities (Altemeyer, 1981) - all concern the relation of the individual to the group. Thus, in Duckitt's view, authoritarianism is primarily an intragroup phenomenon concerning individuals' or groups' attitudes about what the relationship between individuals and their in-groups should be. By comparison, SDO concerns individuals' attitudes about what kind of relationship should exist between in-groups and outgroups, which is an intergroup phenomenon.

\section{SDO Versus Political-Economic Conservatism}

The other well-known individual predictor of social and political attitudes is political-economic conservatism. The power of political-economic conservatism to predict social and political attitudes and candidate preference is far too robust to refute. In fact, we postulate that political-economic conservatism is a prototypic legitimizing myth: an ideology that separates people into groups and suggests that some groups should be accorded more positive social value (e.g., tax breaks, funds for schools, and access to health care), whereas other groups should be allocated more negative social value (e.g., prison terms, censorship, and layoffs).

Our analysis of conservatism as a legitimizing myth can explain why, in many previous studies, conservatism was correlated with racism (e.g., Dator, 1969; Levinson, 1950; Sidanius \& Ekehammar, 1979; Stone \& Russ, 1976). We believe politicaleconomic conservatism and racism are spuriously correlated and that both are "driven" by SDO. In fact, recent studies have shown that there was no significant residual correlation between political-economic conservatism and racism once SDO was controlled (see Sidanius \& Pratto, 1993a, 1993b; Sidanius et al., 1992).

We believe SDO has significant power to predict policy attitudes over and above political-economic conservatism. In the present study, virtually all partial correlations between policy attitudes and SDO, controlling for political-economic conservatism, were reliable. Part of the advantage SDO may have over political-economic conservatism is that SDO is an attitudinal orientation rather than a policy doctrine and therefore does not require expertise or deliberate application. That is, to formulate a policy attitude consistent with one's political ideology, one must have a thorough understanding of that ideology and think through or know how it "should" apply to the acceptance of new policy initiatives. In contrast, one's SDO level will provide a gut reaction to new policy initiatives that imply changes in intergroup relations, essentially "I like it" or "I don't like it." In other words, we expect SDO to be a better predictor of grouprelevant social and political attitudes than political-economic conservatism among nonideologues, whenever thoughtful ideological reasoning is not engaged, and for new social attitudes. 
The present results can be compared with Wilson's (e.g., 1973) extensive work on conservatism as an attitudinal orientation, rather than as an ideology. Wilson found that conservatism was a convenient label for describing the dimension underlying a similar constellation of ideological beliefs and policy attitudes to those we have shown to relate to SDO: racism, nationalism, ethnocentrism, militarism, law and order, and proestablishment politics. Conceptually, our definition of SDO differs from Wilson's conservatism in that we have not included fundamentalist religiosity, antihedonism, or strict morality as part of SDO. Our supposition is that those beliefs are particularly Western legitimizing myths that happen to be held by people who make distinctions between superior and inferior or deserving and undeserving people in a Calvinist vein, but that they would not necessarily be related to SDO in all cultural contexts. Likewise, it seems that forms of ethnic prejudice other than antiBlack racism would be more powerfully related to SDO in certain other cultural contexts. The comparison between SDO and attitudinal conservatism highlights that our measure of SDO is relatively independent of particular cultural beliefs or policies. That is, our items do not specify which groups of people are referred to (with the exception of nations) because we felt that a general orientation toward groups could predict attitudes toward specific groups or specific group-relevant policies.

We modified our SDO scale so that it related to our conceptual definition more strongly by making each item refer only to the generic concept group. We compared the 14-item scale in Appendix A with this new scale in a sample of 199 Stanford students. We administered the 14-item SDO scale $(\alpha=.88)$ and a brief policy attitude survey with a 1 (very negative) to 7 (very positive) response format. Four weeks later, we administered the balanced 16-item SDO scale shown in Appendix C $(\alpha=.91)$. The two scales correlated .75 with one another $(p<.01)$, comparable with the cross-time reliability correlation of the 14-item SDO scale. Both SDO scales correlated significantly with the policy attitudes in the directions expected and to very similar degrees. The 14- and 16-item SDO scales correlated, respectively, with attitudes toward affirmative action $(r \mathrm{~s}=-.34,-.44)$, civil rights $(-.51,-.59)$, gay rights $(-.36,-.32)$, the military $(.40, .39)$, decreased immigration $(.37, .41)$, equal pay for women $(-.38,-.29)$, and the death penalty $(.40, .34)$, all $p s<$ .01 . We also tested an abbreviated scale consisting of Items 1, 3, $4,7,10,12,13$, and 14 in Appendix $\mathrm{C}(\alpha=.86)$, which correlated in nearly the same magnitudes with the policy items above. We administered the 16-item SDO scale to another sample of 245 Stanford students along with the Rombough and Ventimiglia (1981) sexism scale. In this second sample, the 16-item scale was internally reliable $(\alpha=.91)$ and correlated $.51(p<$ $.01)$ with the sexism scale and .26 with subject sex $(p<.01)$. The abbreviated (8-item) version of this scale was internally reliable $(\alpha=.86)$ and correlated .47 with sexism $(p<.01)$ and .26 with subject sex $(p<.01)$. The 16-item scale (and its 8 -item abbreviated form) has slightly more face validity than the 14item SDO scale, and it seems to have similar properties.

\section{SDO and the Dynamics of Oppression}

Our present focus on SDO is not meant to imply that all phenomena related to prejudice and group conflict can be solely understood or reduced to individual differences. In fact, social dominance theory implies that SDO and other individual variables must be considered within their social context, because individual variables and social-structural variables have a dynamic relationship.

For example, our data suggest that empathy with other persons may be a significant attenuator of SDO. However, concern for others (particularly out-group members) is not just a fixed individual propensity, but instead seems likely to be influenced by social structures and policies. Social structures and policies that prevent the formation of close relationships and empathy between high- and low-status persons (e.g., economically or legally enforced segregation, language barriers, publishing biases), would seem to discourage empathy, between groups and the formation of a common identity. These factors, along with the desire for group-based status and the presumption of status or privilege, may also give rise to SDO. An important enterprise for future research is to investigate the social contextual factors that contribute to SDO and to inequality in general.

As a causal variable, we believe SDO is pertinent to the dynamics of group conflict and institutional discrimination. In the remainder of our discussion, we focus on these ramifications.

\section{SDO and Group Discrimination}

Social dominance theory states that SDO should predict prejudice and discrimination against out-groups; social identity theory (e.g., Tajfel \& Turner, 1986) implies that emotional affiliation or identification with one's in-group should do the same. Social identity theory posits out-group denigration as a device for maintaining positive social identity; social dominance theory posits it as a device to maintain superior group status. In a minimal groups experiment, SDO and in-group identification each predicted degree of out-group discrimination (Sidanius, Pratto, \& Mitchell, 1994). However, these effects were not independent-those who were high on SDO and on in-group identification were even more discriminatory against a minimal out-group. Crocker and Luhtanen (1990) found a parallel interaction in another experiment: People who strongly affiliated with their in-groups and whose group status was threatened especially denigrated out-groups. We consider their results to be consistent with both theories in that both group identification and group status needs motivated greater discrimination. Levin and Sidanius (1993) found a similar interaction between SDO and group status; high-SDO subjects who belonged to artificially high-status groups especially denigrated out-group members. High group status and group-status threat may work similarly in these studies because high-status groups, having the most status to lose, may experience the most threat when confronted by possible loss of status. Understanding the circumstances under which people have high levels of in-group identification, high group status, and high SDO, then, appears to be important for understanding when discrimination is likely to be especially severe. Some of our other research has addressed the question of when these three predictors of discrimination will co-occur.

Because SDO is the desire for one's group to dominate others, SDO should have a differential relationship to in-group identification depending on the group's level of social status. Sidanius, Pratto, and Rabinowitz (1994) documented that SDO and in- 
group identification were more positively correlated in higher status than in lower status groups. Using various ethnic identification measures, we showed that the covariance between ethnic identification and SDO was statistically significant and positive within a high-status group (i.e., Euro-Americans), whereas this relationship was statistically significant and negative within a low-status group (Hispanics and African-Americans).

These experimental and correlational findings suggest that high-status groups will be the most discriminatory against outgroups because their members are most likely to have both high SDO levels and high levels of in-group identification. It is important to remember that these two variables, in experimental studies, interact to cause extremely severe out-group discrimination. In total, these results support social dominance theory's contention that higher status groups will tend to be more ingroup serving than lower status groups. That is, higher status groups are more discriminatory against out-groups than lower status groups, and the aggregate affect of this asymmetry is not equal groups in conflict, but the maintenance of hierarchical group relations (see Sidanius \& Pratto, 1993a).

\section{SDO and Social Role}

By performing organizational roles, individuals greatly expand their capacity for group discrimination because collective institutions can often allocate resources or costs on a far larger scale than individuals can. Therefore, institutional discrimination is one of the major contributors to the creation and maintenance of social inequalities and social hierarchy (e.g., Feagin \& Feagin, 1978). The individual organizational member, however, is not insignificant. An organization's members help an institution perform its hierarchy role by endorsing legitimizing myths and adapting their SDO levels to the institution's norms. Several processes may contribute to a match between individuals and institutions. There is mounting evidence that people seek roles in an institution compatible with their SDO levels and ideological beliefs. The present research showed two replications of this relationship between SDO and aspired hierarchy role. A previous study showed the same relationship between aspired hierarchy role and belief in legitimizing myths (Sidanius, Pratto, Martin, \& Stallworth, 1991). In another study, police recruits were found to have significantly higher SDO levels and related attitudes than public defenders (Sidanius, Liu, Pratto, \& Shaw, 1994). Self-selection into roles based on hierarchy-relevant ideologies may be a contributing factor to institutional discrimination.

An institution also reinforces and contributes to the match between individuals' attitudes and institutional hierarchy role. For example, White police academy recruits became increasingly more negative toward Blacks during their first 18 months as police (Teahan, 1975). Also, the initial racial attitudes of intended hierarchy enhancers resisted the usual liberalizing influence of college the longer they stayed in college (Sidanius, Pratto, Martin, \& Stallworth, 1991). Any number of socialization or social influence processes may have caused such effects. Hierarchy-enhancing behaviors or attitudes may even be rewarded by hierarchy-enhancing institutions. One study of campus police officers showed that those who were most successful in their careers, as evidenced by several measures such as superior's evaluations and salary increases, tended to score higher on measures of racism and ethnocentrism (Leitner \& Sedlacek, 1976). More recently, in a study of the Los Angeles Police Department, the Christopher Commission (1991) found that those police officers with the highest number of civilian complaints for brutality and excessive force received unusually positive performance evaluations from their supervising officers. In addition, these supervisor evaluations "were uniformly optimistic about the officers' progress and prospects on the force" (Christopher et al., 1991, p. 41).

Apparently, individuals and institutions reinforce each other's hierarchy-enhancing tendencies, which we believe makes their discriminatory behaviors powerful and difficult to change. More research on the detailed processes by which individuals and institutions reinforce one another's prejudices may be useful to those seeking to reduce institutional discrimination.

To summarize, the present research indicates that SDO, the desire for group dominance, is a significant predictor of social and political attitudes pertaining to intergroup relations and also of hierarchy roles. Social dominance theory suggests that the confluence of this individual-difference variable and a number of social factors including lack of common identity, high ingroup status, and social role, contributes to the oppression of social groups.

\section{References}

Adorno, T. W., Frenkel-Brunswik, E., Levinson, D. J., \& Sanford, R. N. (1950). The authoritarian personality. New York: Norton.

Altemeyer, B. (1981). Right-wing authoritarianism. Manitoba: University of Manitoba Press.

Avery, P. G. (1988). Political tolerance among adolescents. Theory and Research in Social Education, 16, 183-201.

Benson, P. L., \& Vincent, S. (1980). Development and validation of the sexist attitudes toward women scale. Psychology of Women Quarterly, 5, 276-291

Bienen, L., Alan, N., Denno, D. W., Allison, P. D., \& Mills, D. L. (1988). The reimposition of capital punishment in New Jersey: The role of prosecutorial discretion. Rutgers Law Review (Fall).

Bobo, L. (1983). Whites' opposition to busing: Symbolic racism or realistic group conflict? Journal of Personality and Social Psychology, $45,1196-1210$.

Brown, D. E. (1991). Human universals. New York: McGraw-Hill.

Burt, M. R. (1980). Cultural myths and supports for rape. Journal of Personality and Social Psychology, 38, 217-230.

Carmines, E. G., \& McIver, J. D. (1981). Analyzing models with unobserved variables: Analysis of covariance structures. In G. W. Bohinstedt \& E. F. Borgatta (Eds.), Social measurement: Current issues (pp. 65-115). Beverly Hills, CA: Sage.

Christopher, W., Arguellas, J. A., Anderson, R. A., Barnes, W. R., Estrada, L. F., Kantor, M., Mosk, R. M., Ordin, A. S., Slaughter, J. B., \& Tranquada, R. E. (1991). Report of the Independent Commission on the Los Angeles Police Department. Suite 1910, 400 South Hope Street, Los Angeles, CA 90071-2899.

Costa, P. T., \& MacRae, R. R. (1985). The NEO Personality Inventory Manual. Odessa, FL: Psychological Assessment Resources.

Crocker, J., \& Luhtanen, R. (1990). Collective self-esteem and in-group bias. Journal of Personality and Social Psychology, 58, 60-67.

Dator, J. A. (1969). What's left of the economic theory of discrimination? In S. Shulman \& W. Darity, Jr. (Eds.), The question of discrimination: Racial inequality in the U.S. labor market (pp. 335-374). Middletown, CT: Wesleyan University Press.

Davis, M. H. (1983). Measuring individual differences in empathy: Evidence for a multidimensional approach. Journal of Personality and Social Psychology, 44, 113-126. 
Depret, E. F., \& Fiske, S. T. (1993). Social cognition and power: Some cognitive consequences of social structure as a source of control deprivation. In G. Weary, F. Gleicher, \& K. L. Marsh (Eds.), Control motivation and social cognition (pp. 176-202). New York: Springer Verlag.

Duckitt, J. (1989). Authoritarianism and group identification: A new view of an old construct. Political Psychology, 10, 63-84.

Eisler, R., \& Loye, D. (1983). The "failure" of liberalism: A reassessment of ideology from a feminine-masculine perspective. Political Psychology, 4, 375-391.

Ekehammar, B., \& Sidanius, J. (1982). Sex differences in socio-political ideology: A replication and extension. British Journal of Social Psychology, 21, 249-257.

Eysenck, H. J. (1971). Social attitudes and social class. British Journal of Social and Clinical Psychology, 10, 210-212.

Eysenck, H. J., \& Wilson, O. D. (1978). The psychological basis of ideology. Baltimore, MD: University Park Press.

Feagin, J. R., \& Feagin, C. B. (1978). Discrimination American style: Institutional racism and sexism. Malabar, FL: Krieger.

Fenigstein, A., Scheier, M. F., \& Buss, A. H. (1975). Public and private self-consciousness: Assessment and theory. Journal of Consulting and Clinical Psychology, 43, 522-527.

Frenkel-Brunswik, E. (1948). A study of prejudice in children. Human Relations, 1, 295-306.

Frenkel-Brunswik, E. (1949). Intolerance of ambiguity as an emotional and perceptual variable. Journal of Personality, 18, 108-143.

General Accounting Office. (1990). Death penalty sentencing: Research indicates pattern of racial disparities. United States General Accounting Office, Report to Senate and House Committees on the Judiciary (GAO/GGD-90-57). Washington, DC: Government Printing Office.

Goertzel, T. G. (1987). Authoritarianism of personality and political attitudes. Journal of Social Psychology, 127, 7-18.

Gough, H. (1987). California Psychological Inventory: Administrator's guide. Palo Alto, CA: Consulting Psychologists Press.

Heaven, P. C. L. (1985). Construction and validation of a measure of authoritarian personality. Journal of Personality Assessment, 49, 545-551.

Jackson, D. N. (1965). Personality Research Form. Goshen, NY: Research Psychologists Press.

Jackson, D. N. (1976). Jackson Personality Inventory. Goshen, NY: Research Psychologists Press.

John, O. P. (1990). The Big Five factor taxonomy: Dimensions of personality in the natural language and in questionnaires. In L. A. Pervin (Ed.), Handbook of personality psychology: Theory and research (pp. 66-100). Hillsdale, NJ: Erlbaum.

John, O. P., Donahue, E., \& Kentle, R. L. (1992). The Big Five Inventory: Versions $4 a$ and 54. Technical Report, Institute of Personality Assessment and Research.

Katz, I., \& Hass, R. G. (1988). Racial ambivalence and American value conflict: Correlational and priming studies of dual cognitive structures. Journal of Personality and Social Psychology, 55, 893-905.

Kleck, G. (1981). Racial discrimination in criminal sentencing: A critical evaluation of the evidence with additional evidence on the death penalty. American Sociological Review, 46, 783-805.

Kluegel, J. R., \& Smith, P. M. (1986). Beliefs about inequality: Americans'views of what is and what ought to be. Hawthorne, NY: Aldine de Gruyter.

Kosterman, R., \& Feshbach, S. (1989). Toward a measure of patriotic and nationalistic attitudes. Political Psychology, 10, 257-274.

Leitner, D. W., \& Sedlacek, W. E. (1976). Characteristics of successful campus police officers. Journal of College Student Personnel, 17, 304-308.

Levin, S. L., \& Sidanius, J. (1993). Intergroup biases as a function of social dominance orientation and in-group status. Unpublished manuscript, University of California at Los Angeles.
Levinson, D. J. (1950). Politico-economic ideology and group memberships in relation to ethnocentrism. In T. Adorno, E. Frenkel-Brunswik, D. J. Levinson, \& R. N. Sanford (Eds.), The authoritarian personality (pp. 151-207). New York: Norton.

Lipset, S. M. (1960). Political man. London: Heinemann.

Loevinger, J. (1957). Objective tests as instrument of psychological theory. Psychological Reports, Monograph Supplement 9.

Malle, B. F., \& Horowitz, L. M.(1994). The puzzle of negative self-views. An explanation using the schema concept. Unpublished manuscript, Stanford University.

Markus, H. R., \& Kitayama, S. (1991). Culture and the self: Implications for cognition, emotion, and motivation. Psychological Review, 98, 224-253.

McConahay, J. B. (1986). Modern racism, ambivalence, and the modern racism scale. In J. F. Dovidio \& S. L. Gaertner (Eds.), Prejudice, discrimination, and racism (pp. 91-125). San Diego, CA: Academic Press.

Mirels, H. L., \& Garrett, J. B. (1971). The Protestant ethic as a personality variable. Journal of Consulting and Clinical Psychology, 36, 4044.

Mitchell, M. (1993). Attitudes towards the death penalty and use of executions: A social dominance perspective. Unpublished dissertation, Department of Psychology, University of California at Los Angeles.

Moynihan, D. P. (1965). The Negro family: The case for national action. Washington, DC: Office of Policy Planning and Research, U.S. Department of Labor.

Nickerson, S., Mayo, C., \& Smith, A. (1986). Racism in the courtroom. In J. F. Dovidio \& S. L. Gaertner (Eds.), Prejudice, discrimination, and racism (pp. 255-278). San Diego, CA: Academic Press.

Paternoster, R. (1983). Race of victim and location of crime: The decision to seek the death penalty in South Carolina. Journal of Criminal Law and Criminology, 74, 754-785.

Peterson, B. E., Doty, R. M., \& Winter, D. G. (1993). Authoritarianism and attitudes towards contemporary social issues. Personality and Social Psychology Bulletin, 19, 174-184.

Pratto, F. (in press). Sexual politics: The gender gap in the bedroom and the cabinet. In D. M. Buss \& N. Malamuth (Eds.), Sex, power, and conflict: Evolutionary and feminist perspectives. New York: Oxford University Press.

Pratto, F., Sidanius, J., \& Stallworth, L. M. (1993). Sexual selection and the sexual and ethnic basis of social hierarchy. In L. Ellis (Ed.), Social stratification and socioeconomic inequality: A comparative biosocial analysis (pp. 111-137). New York: Praeger.

Radelet, M. L., \& Pierce, G. L. (1985). Race and prosecutorial discretion in homicide cases. Law and Society Review, 19, 587-621.

Ray, J. (1976). Do authoritarians hold authoritarian attitudes? Human Relations, 29, 307-325.

Reiman, J. (1990). The rich get richer and the poor get prison: Ideology, class, and criminal justice. New York: Macmillan.

Rombough, S., \& Ventimiglia, J. C. (1981). Sexism: A tri-dimensional phenomenon. Sex Roles, 7, 747-755.

Rosenberg, M. (1965). Society and the adolescent self image. Princeton, NJ: Princeton University Press.

Rosenthal, R. (1986). Meta-analytic procedures for social research. Beverly Hills, CA: Sage.

Rubin, Z., \& Peplau, L. A. (1975). Who believes in a just world? Journal of Social Issues, 31, 265-289.

Sears, D. O. (1988). Symbolic racism. In P. A. Katz \& D. A. Taylor (Eds.), Eliminating racism: Profiles in controversy (pp. 53-84). New York: Plenum.

Shapiro, R. Y., \& Mahajan, H. (1986). Gender differences in policy preferences: A summary of trends from the 1960s to the 1980s. Public Opinion Quarterly, 50, 42-61.

Sidanius, J. (1976). Further tests of a Swedish Scale of Conservatism. Reports from the Department of Psychology, University of Stockholm, Supplement 36. 
Sidanius, J. (1988). Race and sentence severity: The case of American justice. Journal of Black Studies, 18, 273-281.

Sidanius, J. (1993). The psychology of group conflict and the dynamics of oppression: A social dominance perspective. In W. McGuire \& S. Iyengar (Eds.), Current approaches to political psychology (pp. 183219). Durham, NC: Duke University Press.

Sidanius, J., Cling, B. J., \& Pratto, F. (1991). Ranking and linking behavior as a function of sex and gender: An exploration of alternative explanations. Journal of Social Issues, 47, 131-149.

Sidanius, J., Devereux, E., \& Pratto, F. (1992). A comparison of symbolic racism theory and social dominance theory as explanations for racial policy attitudes. Journal of Social Psychology, 132, 377-395.

Sidanius, J., \& Ekehammar, B. (1979). Political socialization: A multivariate analysis of Swedish political attitude and preference data. $E \boldsymbol{U}$ ropean Journal of Social Psychology, 9, 265-279.

Sidanius, J., \& Ekehammar, B. (1980). Sex-related differences in sociopolitical ideology. Scandinavian Journal of Psychology, 21, 17-26.

Sidanius, J., Liu, J., Pratto, F., \& Shaw, J. (1994). Social dominance orientation, hierarchy-attenuators and hierarchy-enhancers: Social dominance theory and the criminal justice system. Journal of Applied Social Psychology, 24, 338-366.

Sidanius, J., \& Pratto, F. (1993a). The dynamics of social dominance and the inevitability of oppression. In P. Sniderman \& P. E. Tetlock (Eds.), Prejudice, politics, and race in America today (pp. 173-211). Stanford, CA: Stanford University Press.

Sidanius, J., \& Pratto, F. (1993b). Racism and support of free-market capitalism: A cross-cultural analysis. Political Psychology, 14, 383403.

Sidanius, J., Pratto, F., \& Bobo, L. (in press). Social dominance orientation and the political psychology of gender: A case of invariance? Journal of Personality and Social Psychology.

Sidanius, J., Pratto, F., \& Brief, D. (1993). Group dominance and the political psychology of gender: A cross-cultural comparison. Unpublished manuscript, University of California at Los Angeles.

Sidanius, J., Pratto, F., Martin, M., \& Stallworth, L. M. (1991). Con- sensual racism and career track: Some implications of social dominance theory. Political Psychology, 12, 691-720.

Sidanius, J., Pratto, F., \& Mitchell, M. (1994). In-group identification, social dominance orientation, and differential intergroup social allocation. Journal of Social Psychology, 134, 151-167.

Sidanius, J., Pratto, F., \& Rabinowitz, J. (1994). Gender, ethnic status, and ideological asymmetry: Social dominance interpretation. Journal of Cross-Cultural Psychology, 25, 194-216.

Sniderman, P. M., \& Tetlock, P. E. (1986a). Symbolic racism: Problems of motive attribution in political analysis. Journal of Social Issues, 42, 129-150.

Sniderman, P. M., \& Tetlock, P. E. (1986b). Reflections on American racism. Journal of Social Issues, 42, 173-188.

Snyder, M. (1974). The self-monitoring of expressive behavior. Journal of Personality and Social Psychology, 30, 526-537.

Spence, J. T., Helmreich, R., \& Stapp, J. (1974). The personal attributes questionnaire: A measure of sex role stereotypes and masculinityfemininity. ISAS Catalog of Selected Documents in Psychology, 4, 1 42.

Stacey, B. G., \& Green, R. T. (1968). The psychological bases of political allegiance among white-collar males. British Journal of Social and Clinical Psychology, 7, 45-60.

Stacey, B. G., \& Green, R. T. (1971). Working-class conservatism: A review and an empirical study. British Journal of Social and Clinical Psychology, 10, 10-26.

Stone, W. F., \& Russ, R. C. (1976). Machiavellianism as tough-mindedness. Journal of Social Psychology, 98, 213-220.

Super, D. E., \& Nevill, D. D. (1985). The values scale. Palo AIto, CA: Consulting Psychologists Press.

Tajfel, H., \& Turner, J. C. C. (1986). The social identity theory of intergroup behavior. In S. Worchel \& W. G. Austin (Eds.), Psychology of intergroup relations (pp. 7-24). Chicago: Nelson-Hall.

Teahan, J. E. (1975). A longitudinal study of attitude shifts among Black and White police officers. Journal of Social Issues, 31, 47-56.

Wilson, G. D. (Ed.). (1973). The psychology of conservatism. San Diego, CA: Academic Press.

Wilson, G. D., \& Patterson, J. R. (1968). A new measure of conservatism. British Journal of Social and Clinical Psychology, 1, 264-269.

\section{Appendix A}

\section{Items on the Social Dominance Orientation Scale}

1. Some groups of people are simply not the equals of others.

2. Some people are just more worthy than others.

3. This country would be better off if we cared less about how equal all people were.

4. Some people are just more deserving than others.

5. It is not a problem if some people have more of a chance in life than others.

6. Some people are just inferior to others.

7. To get ahead in life, it is sometimes necessary to step on others.

8. Increased economic equality.

9. Increased social equality.
10. Equality.

11. If people were treated more equally we would have fewer problems in this country.

12. In an ideal world, all nations would be equal.

13. We should try to treat one another as equals as much as possible. (All humans should be treated equally.)

14. It is important that we treat other countries as equals.

All items were measured on a very negative (1) to very positive (7) scale. Items 8-14 were reverse-coded. The version of Item 13 in parentheses was used in Samples 5-12. The order of items differed from above and across samples. 


\section{Appendix B}

\section{Items Used on Scales}

Samples 2, 3b, 4, 5, 6, 8, 9: Items Comprising the Original Legitimizing Myths Scales

Anti-Black Racism Scale

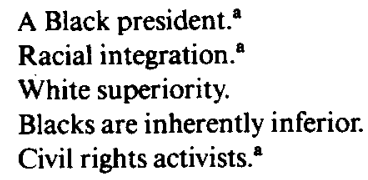

\section{Anti-Arab Racism Scale}

Most of the terrorists in the world today are Arabs.

Historically, Arabs have made important contributions to world culture. ${ }^{a}$

Iraqis have little appreciation for democratic values.

People of the Muslim religion tend to be fanatical.

Muslims value peace and love. ${ }^{\mathrm{a}}$

\section{Cultural Elitism Scale}

The poor cannot appreciate fine art and music.

No amount of education can make up for the wrong breeding.

Qualifications and not personality should determine whether a candidate gets votes.

The ideal world is run by those who are most capable.

Western civilization has brought more progress than all other cultural traditions.

Someone who treats other people poorly but is very good at his job should be promoted.

Great art is not meant for the common folk.

\section{Equal Opportunity Scale}

In America, every person has an equal chance to rise up and prosper. Lower wages for women and ethnic minorities simply reflect lower skill and education levels.

America is the "land of opportunity."

Salaries are usually reflective of education, which in turn is reflective of intelligence and ambition.

Affirmative Action prevents the more-qualified from attaining positions.

Potential to do well should not be sufficient for admission to any program. Only those with proven competence in that field should be allowed.

\section{Patriotism Scale}

Flag burning should be illegal.

In American public schools, every day should begin with the Pledge of Allegiance.

I supported the United States' actions in Iraq.

Patriotism is the most important qualification for a politician.

I believe in mandatory military service by all citizens of the United States in the armed forces.

It was disloyal for people to question the President during the Iraq war.

With few exceptions, the American government does a good and honest job.
Other countries should be happy to have American intervention and influence.

I am proud to be an American.

Congressman who voted against the war should be removed from office.

The United States suffers when patriotism wanes.

Patriots are the ones who have made this country great.

\section{Nationalism Scale}

In view of America's moral and material superiority, it is only right that we should have the biggest say in deciding United Nations policy.

This country must continue to lead the "Free World."

We should do anything necessary to increase the power of our country, even if it means war.

Sometimes it is necessary for our country to make war on other countries for their own good.

The important thing for the U.S. foreign aid program is to see to it that the U.S. gains a political advantage.

Generally, the more influence America has on other nations, the better off they are.

\section{Noblesse Oblige Scale-Form A}

As a country's wealth increases, more of its resources should be channeled to the poor.

The more money one makes, the greater proportion of that money should be paid in taxes.

Those with more resources have more obligations toward their fellow human beings.

Giving to others usually benefits the givers as well.

The man with two coats in his closet should give one away.

Extra food on the table belongs to those who are hungry.

\section{Noblesse Oblige Scale-Form B}

As a country's wealth increases, more of its resources should be channeled to the poor.

Giving to others usually benefits the givers as well.

Those with more resources have more obligations toward their fellow human beings.

It is beneficial to all to spend money on the public sector such as education, housing, and health care.

Those who are well off can't be expected to take care of everyone else. ${ }^{2}$ Social charities just create dependency."

\section{Samples 2, 3b, 5, 6, 8, 9: Items on the Policy Scales}

\section{Law and Order Policies}

Death penalty for drug kingpins.

Death penalty.

Prisoner's rights. , $, \mathrm{b}, \mathrm{c}^{-}$

Longer prison sentences. ${ }^{d}$

\section{Gay Rights}

Gay or lesbian marriage.

Gay and lesbian rights. 


\section{Women's Rights}

Guaranteed job security after maternity leave.

Stiffer penalties for wife beating. ${ }^{c}$

Equal pay for women.

More women judges.

\section{Social Programs}

Government sponsored health care.

Better support for the homeless.

More support for early education. ${ }^{c, d}$

Free school lunches. ${ }^{\mathrm{c}, \mathrm{d}}$

Low income housing. ${ }^{\text {c,d }}$

Arresting the homeless. ${ }^{\mathrm{s}, \mathrm{c}}$

Guaranteed jobs for all.

Reduced benefits for the unemployed."

Greater aid to poor kids.

Increased taxation of the rich.

\section{Racial Policy}

Racial quotas

Affirmative action.

School busing. ${ }^{\mathrm{e}}$

Civil rights.

Helping minorities get a better education.

Government helping minorities get better housing.

Government has no business helping any particular ethnic group in the job market."

\section{Military Programs}

Decreased defense spending. ${ }^{2}$

Strategic Defense Initiative.

B-2 (Stealth) bomber.

Going to war.

\section{Environmental Policies}

Drilling for oil off the California coast."

Government-mandated recycling programs.

Taxing environmental polluters to pay for superfund clean ups.

More government involvement on clean air and water.

Drilling for oil under the Arctic National Wildlife Refuge. ${ }^{\text {a }}$

\section{Chauvinism Scale}

Central Intelligence Agency (CIA).

English as the official language.

Decreased immigration to the U.S.

National security.

American way of life.

No welfare for new immigrants.

America first.

America as world's policeman.

\section{Sample 4: Iraq War Scales (January, 1991)}

Favors Military Action by U.S.

The U.S. really had no choice but to use military force against Iraq. The U.S. should not be using military force against Iraq."

Saddam Hussein must be stopped by any means necessary-including nuclear weapons.
The U.N. coalition should not participate in any military action that will kill civilians no matter how few."

The U.N. coalition should cease bombing Iraq and offer to negotiate.

\section{Willing to Make Sacrifices for War}

It would be worth our country's having a lower standard of living to maintain world peace. ${ }^{\mathrm{a}}$

I would be willing to pay double the current prices of gasoline to avoid similar conflicts over oil in the future."

I am willing to risk my life to help with the war effort in the Persian Gulf.

I'd be willing to pay higher taxes to finance the war in the Gulf.

\section{Favors Suspending Liberties for War}

President Bush should be given whatever power he needs to conduct war.

Sometimes political leaders must be unencumbered by legislatures so that they can govern effectively.

It is appropriate to reinstitute the military draft to help with the conflict with Iraq.

Military censorship of the press is appropriate in times of war.

\section{Concerned About Environment in War}

Iraq should be held entirely responsible for cleaning up the oil spills in the Persian Gulf.

The U.S. is partly to blame for the environmental damage to the Persian Gulf region."

Potential environmental damage should have been considered in the decision to go to war."

Sample 8: Post-War Pro-Iraq War Items (February, 1992)

The U.S. had no choice but to begin bombing Iraq on January 16 , 1991.

The U.S. should have tried political and economic pressure for a longer time before bombing Iraq."

Bombing the cities of Iraq was justified.

The President went to war to increase his popularity.

The U.S. could have prevented more civilian casualties in Iraq.

The Gulf War wasn't worth the human cost. ${ }^{\text {a }}$

The U.N. Coalition really taught Hussein a lesson.

We should spend as much money and effort on solving domestic problems as we did on the Iraq war."

Once there was 250,000 U.S. troops in the Persian Gulf region, it would have been embarrassing not to "use" them in war.

President Bush should not have set a date for Iraqi withdrawal from Kuwait. $^{\text {a }}$

Strict control of the press coverage of the Iraq war was necessary.

If we understood the Iraqis better, we might have been able to avoid the war. ${ }^{\mathrm{a}}$

In all, the press reports we received about the war were fair and impartial.

The military response to Iraq's invasion of Kuwait will probably discourage others from invading countries.

The Gulf War wasn't worth the environmental cost."

\section{Wars of Dominance}

To insure our influence is felt in that nation.

To protect our economic interests.

To protect our citizens being held hostage

For U.S. national security purposes. 
To restore a freely elected government which had been overthrown by a military coup.

To keep an enemy from acquiring chemical or nuclear weapons.

If we started disarming, it would only lead to more war.

A U.S. Military presence helps maintain peace.

\section{Humanitarian Wars}

To ensure that human rights were respected in that country. To ensure that emergency food supplies could reach civilians. To protect unarmed civilians from battles.

Ultimatums usually lead to war, rather than diplomatic solutions. By selling arms to other countries, we increase the likelihood of war. War should always be considered a last resort.

\section{Sample 10: Items on Death Penalty Survey}

\section{Favored Executing Harris}

I felt that Robert Alton Harris' death sentence should have been commuted to life in prison without possibility of parole. ${ }^{a}$

I felt that Robert Alton Harris should have been executed.

\section{Believes in Specific Deterrence}

If not executed, murderers will commit more crimes in the future.

We don't need the death penalty to insure that a murderer never repeats his crime. ${ }^{\mathrm{a}}$

If not executed, a murderer will be on the street in a few years.

\section{Support for Painful Executions}

Murderers should suffer when they are executed.

I might support the use of burning alive to execute those who commit the most heinous crimes.

If people have to be executed, they should be executed in the most painless way possible."

The electric chair should be quick and painless.

Executions should be as bloodless as possible."

The crime problem has gotten so bad that maybe we should bring back public hangings.

We should use more graphic forms of executions (such as a firing squad).

When using the electric chair for executions, the voltage should be applied slowly so the criminal suffers before dying.

\section{Belief in Retribution \\ Society does not have the right to get revenge for murder. ${ }^{\text {a }}$ \\ For a terrible crime, there should be a terrible punishment. \\ Even the worst criminal should be considered for mercy. \\ Those who hurt others deserve to be hurt in return. \\ Punishment should fit the crime.}

Note. Response scale for all items was strongly disagree (1) to strongly agree (7) except for the nationalism, anti-Black racism, and chauvinism items, which were very negative (1) to very positive (7). The instructions for the Wars scales were to indicate how much the subject agreed or disagreed that his or her country would be justified in using military force (for the items beginning with "to" or "for") or agreement or disagreement with support for military use of force in general (for items that are complete sentences).

${ }^{a}$ Item was reverse-coded. ${ }^{b}$ Item was omitted in Sample 6. ${ }^{\mathrm{c}}$ Item was omitted in Sample 8. 'Item was omitted in Sample 9. ' $I$ Item was omitted in Sample 2.

\section{Appendix C}

Items on the 16-Item Social Dominance Orientation Scale

1. Some groups of people are simply inferior to other groups.

2. In getting what you want, it is sometimes necessary to use force against other groups.

3. It's $O K$ if some groups have more of a chance in life than others.

4. To get ahead in life, it is sometimes necessary to step on other groups.

5. If certain groups stayed in their place, we would have fewer problems.

6. It's probably a good thing that certain groups are at the top and other groups are at the bottom.

7. Inferior groups should stay in their place.

8. Sometimes other groups must be kept in their place.

9. It would be good if groups could be equal.

10. Group equality should be our ideal.
11. All groups should be given an equal chance in life.

12. We should do what we can to equalize conditions for different groups.

13. Increased social equality.

14. We would have fewer problems if we treated people more equally.

15. We should strive to make incomes as equal as possible.

16. No one group should dominate in society.

Items $9-16$ should be reverse-coded. The response scale was very negative (1) to very positive (7).

Received July 8, 1993

Revision received May 10, 1994

Accepted May 11, 1994 